KOVID-19: ŠTA SMO NAUČILI OD POČETKA EPIDEMIJE DO DANAS?

PREGLEDNI RAD

REVIEW ARTICLE

\title{
COVID-19: WHAT HAVE WE LEARNED SINCE THE BEGINNING OF THE EPIDEMIC UNTIL TODAY?
}

\section{Ivana Milošević1,2, Ankica Vujović}

${ }^{1}$ Klinika za infektivne i tropske bolesti, Univerzitetski klinički centar Srbije, Beograd, Srbija

2 Medicinski fakultet Univerziteta u Beogradu, Beograd, Srbija

\author{
${ }^{1}$ Clinic for Infectious and Tropical Diseases, University Clinical \\ Center of Serbia, Belgrade, Serbia
}

${ }^{2}$ Faculty of Medicine, University of Belgrade, Belgrade, Serbia

\section{SAŽETAK}

Krajem decembra 2019. godine, u gradu Vuhanu, u Kini, beleži se pojava virusne pneumonije kod velikog broja bolesnika. Ubrzo je otkriven uzročnik ove infekcije - novi koronavirus, nazvan SARS-KoV-2, zbog genetske sličnosti sa virusom koji izaziva teški akutni respiratorni sindrom (SARS-KoV). Infekcija se munjevito proširila na druge kontinente, a pandemija još uvek traje. Klinička slika varira od asimptomatske forme, preko simptoma infekcije gornjih respiratornih puteva, do pneumonije i akutnog respiratornog distres sindroma (ARDS). Starije osobe, imunokompromitovani bolesnici, i bolesnici sa hroničnim internističkim oboljenjima su u riziku za tešku formu bolesti. Virus ulazi u ćelije preko receptora za angiotenzin konvertujući enzim 2 (ACE2), koji su prisutni u praktično svim tkivima u organizmu. Pored intersticijumske pneumonije, patološke promene se sreću i na drugim sistemima organa. U Srbiji je prvi slučaj ove bolesti zabeležen 6 . marta 2020. godine. Veliki broj bolesnika je zahtevao angažovanje zdravstvenih radnika svih profila, te uvođenje velikog broja zdravstvenih ustanova u KOVID sistem. Pojava novog virusa iziskivala je potrebu za novim antivirusnim lekom. Na bazi prethodnog iskustva sa SARS-KoV virusom, korišćeni su antivirusni lekovi poznati od ranije, sa različitim stepenom uspeha. Terapija se menjala u skladu sa novim saznanjima, a od početka epidemije u Srbiji, ustanovljen je Nacionalni protokol Republike Srbije za lečenje KOVID-19 infekcije, koji je išao u korak sa preporukama vodećih svetskih institucija. Najznačajniji događaj u toku pandemije jeste pojava vakcine protiv KOVID-19 infekcije, a vakcinacija u Srbiji je počela decembra 2020. godine. Brzina završetka pandemije zavisi direktno od brzine i efikasnosti vakcinacije, uz druge epidemiološke mere.

Ključne reči: koronavirus, KOVID-19, pandemija, pneumonija

Autor za korespondenciju:

Ankica Vujović

Klinika za infektivne i tropske bolesti, Univerzitetski klinički centar Srbije

Bulevar Oslobođenja 16, 11000 Beograd, Srbija

E-mail: ankica.vujovic88@gmail.com

Primljeno - Received: June 30, 2021;

\begin{abstract}
In late December 2019, in the city of Wuhan, in China, the appearance of unknown viral pneumonia was recorded in a large number of patients. The cause of this infection was soon discovered - a new coronavirus, called SARS-CoV-2, due to its genetic similarity to the virus that causes severe acute respiratory syndrome (SARS-CoV). The infection then spread rapidly to other continents, and the pandemic is still ongoing. The clinical presentation varies from the asymptomatic form to symptoms of upper respiratory tract infection, and finally to pneumonia and acute respiratory distress syndrome (ARDS). The elderly, immunocompromised patients, and patients suffering from chronic, internal medicine diseases are at risk of the severe form of the COVID-19 disease. The virus enters cells via angiotensin converting enzyme 2 (ACE2) receptors, which are present in practically all tissues in the body. In addition to interstitial pneumonia, pathological changes are also found in other organ systems. The first case in Serbia was recorded on March 6, 2020. A large number of patients required the engagement of health workers of all profiles as well as the introduction of a large number of health institutions into the COVID system. The emergence of a new virus necessitated a new antiviral drug. Based on previous experience with the SARS-CoV virus, previously known antiviral drugs have been used, with varying degrees of success. The therapy changed in accordance with new knowledge, and since the beginning of the epidemic in Serbia, the National Protocol of the Republic of Serbia for the Treatment of the COVID-19 Infection has been established, which has kept apace with the recommendations of the world's leading institutions. The most significant event during the pandemic was the development of the vaccine against COVID-19, with vaccination in Serbia beginning in December 2020. How quickly the epidemic will end depends directly on the speed and efficiency of vaccination, along with other epidemiological measures.
\end{abstract}

Key words: coronavirus, COVID-19, pandemic, pneumonia
Corresponding author:

Ankica Vujović

Clinic for Infectious and Tropical Diseases, University Clinical Center of Serbia

16 Bulevar Oslobođenja Street, 11000 Belgrade, Serbia

E-mail: ankica.vujovic88@gmail.com

Prihvaćeno - Accepted: July 2, 2021;

Online first: September 30, 2021. 


\section{UVOD}

Veliki broj epidemija i pandemija u svetu do sada bio je razlog gubitka hiljada do miliona ljudskih života. Uprkos svakodnevnom napretku u medicini, i dalje smo suočeni sa novim patogenima koji predstavljaju pretnju za ljudske živote, globalnu ekonomsku sigurnost i zdravstveni sistem.

Krajem decembra meseca 2019. godine u gradu Vuhanu, u kineskoj provinciji Hubei, zabeležena je pojava pneumonije nepoznatog uzročnika kod velikog broja bolesnika. Zbog brzog javljanja velikog broja novih slučajeva, kineska vlada je 23. januara 2020. godine naredila potpunu blokadu Vuhana. Virus se dalje širio po celom svetu. Prvi slučaj u Srbiji je registrovan 6. marta 2020. godine. Svetska zdravstvena organizacija (SZO) je 11. marta 2020. proglasila pandemiju KOVID-19 infekcije koja i dalje traje [1,2].

Ubrzo po prijavljivanju nove respiratorne bolesti, sekvenciranjem celog genoma i bioinformatičkim analizama, otkrivene su karakteristike tipične za $\beta$-koronavirus sa ovojnicom, kao i genetske sekvence vrlo slične virusu izazivaču teškog akutnog respiratornog sindroma (SARSKoV-1), (podudarnost 80\%) i koronavirusu slepih miševa RaTG13 (podudarnost 96,2\%) [3]. Virus se u početku nazivao novi koronavirus 2019 (2019-nKoV), da bi SZO, naknadno, 11. februara 2020. godine, promenila ime u SARSKoV-2, zbog pomenute velike sličnosti sa SARS-KoV [2].

Koronavirusi pripadaju porodici Coronaviradae, redu Nidovirales, a dele se $u$ četiri glavna roda $(\alpha, \beta, \gamma$ i $\delta)$. Ovi virusi su opisani kao prouzrokovači respiratornih infekcija ljudi još šezdesetih godina 20. veka. Tokom 21. veka, koronavirusi postaju značajni uzročnici teških respiratornih bolesti, i to najpre 2002. godine, kada se pojavio SARS-KoV, potom 2012. godine, pojavom Bliskoistočnog respiratornog sindroma (MERS-KoV), i najzad od decembra 2019. godine, pojavom KOVID-19 (SARS-KoV-2) virusne infekcije. Za sva tri navedena koronavirusa se smatra da su zoonoznog porekla, da se radi o respiratornim infekcijama, te da imaju sposobnost da izazovu teške i fatalne bolesti kod ljudi [4].

\section{PATOGENEZA}

\section{Virusna invazija}

Koronavirusi su dobili ime zbog oblika koji asocira na krunu. Sadrže jednolančanu, pozitivnu ribonukleinsku kiselinu (RNK). Virusna ovojnica je presvučena takozvanim "spajk”, tj. „šiljak" glikoproteinom (S), glikoproteinskim omotačem (E) i membranskim proteinima (M). Protein S omogućava vezivanje za receptor ćelijske membrane, fuziju membrane, i, na kraju, ulazak virusa u ćeliju domaćina. Protein $M$, najrasprostranjeniji membranski protein je, zajedno sa $E$ proteinom, odgovoran za strukturu membrane

\section{INTRODUCTION}

A large number of different epidemics and pandemics in the world have thus far been the cause of the loss of many thousands, even millions of lives. Despite everyday advances in medicine, we are still faced with new pathogens threatening human lives, the global economy and the healthcare system.

Late in December 2019, in the city of Wuhan, the Chinese province of Hubei, pneumonia of unknown origin was detected in a large number of patients. As a very large number of patients were registered in a short period of time, on January 23, 2020, the Chinese government ordered the complete lockdown of Wuhan. The virus continued to spread all over the world. In Serbia, the first case of the disease was registered on March 6, 2020. On March 11, 2020, the World Health Organization (WHO) declared the pandemic of the COVID-19 infection, which is still ongoing [1,2].

Very soon after the emergence of the new respiratory disease, by sequencing the entire genome and through bioinformatic analyses, characteristics typical of the enveloped $\beta$-coronavirus were discovered, as well as genetic sequences very similar to the virus causing severe acute respiratory syndrome (SARS-CoV-1) (80\% match), and the bat coronavirus RaTG13 (96,2\% match) [3]. The new virus was initially named the new coronavirus (2019-nCoV), but was subsequently, on February 11, 2020, renamed by the WHO as SARS-CoV-2, due to the already mentioned great similarity to SARS-CoV [2].

Coronaviruses belong to the family Coronaviradae, the order Nidovirales, and are classified into four main genera $(\alpha, \beta, \gamma$ i $\delta)$. These viruses were first described as the source of respiratory infections in people in the 1960 s. During the $21^{\text {st }}$ century, coronaviruses have become a significant cause of severe respiratory diseases; first in 2002, when the SARS-CoV virus appeared; then in 2012, with the appearance of the Middle East respiratory syndrome (MERS-CoV), and finally, as of December 2019, with the appearance of the COVID-19 (SARSCoV-2) viral infection. It has been determined that all these three viruses are of zoonotic origin, that they cause respiratory infections, and that they have the potential of causing severe and fatal illness in people [4].

\section{PATHOGENESIS}

\section{Viral invasion}

Coronaviruses were thus named due to their shape which resembles a crown. They contain single stranded positive ribonucleic acid (RNA). The viral envelope is coated with the so called 'spike' glycoprotein (S), the glycoprotein envelope (E) and membrane proteins (M). Protein $\mathrm{S}$ enables binding to the cell membrane receptor, membrane fusion, and finally, entry of the virus into 
koronavirusa. Komponenta spiralnog nukleokapsida je N protein, koji je deo RNK lanca [5]. Vezivanje i ulazak u ćeliju domaćina se odvija preko S proteina, koji ima dve podjedinice. S1 podjedinica predstavlja receptor-vezujući segment, dok se S2 podjedinica smatra potencijalnim mestom dejstva antivirusnih lekova. Ciljno mesto vezivanja SARS-KoV-2 virusa je receptor za angiotenzin konvertujući enzim 2 (ACE2), koji se nalazi u različitim organima i ćelijama, uključujući nazofarinks, nosnu i oralnu sluznicu, tanko crevo, debelo crevo, bubreg, jetru, vaskularni endotelijum i epitelne ćelije plućnih alveola (uglavnom pneumociti tipa 2) [6]. Prethodne studije su pokazale da je osetljivost domaćina na infekciju SARS-KoV-2, najverovatnije kao i kod SARS-KoV, određena afinitetom između ACE2 receptora domaćina i virusnog receptor-vezujućeg segmenta. Smatra se da su genetske rekombinacije u receptor-vezujućem regionu $S$ proteina možda uzrok njegove veće stope transmisije u poređenju sa ostalim korona virusima [7]. Nakon ulaska u ćeliju dolazi do oslobađanja virusne RNK, potom do stvaranja $\mathrm{S}, \mathrm{M}$ i E proteina, nukleokapsida, te stvaranja nove virusne partikule koja egzocitozom napušta ćeliju [8,9]. Tokom procesa replikacije, SARS-KoV-2 ima veliku sposobnost korekcije nastalih mutacija, zbog čega se smatra da je stopa mutacija kod ovog virusa niža u odnosu na ostale RNK viruse [6] (Slika 1).

\section{Imunski odgovor na infekciju}

Nakon ulaska virusa u organizam, putem nazofarinksa, dolazi do aktivacije antigen prezentujućih čelija (APC), kao što su dendritične ćelije i makrofagi. To dovodi dalje do aktiviranja humoralnog i ćelijskog imuniteta, posredstvom virus specifičnih B i T limfocita $[9,10]$. Prezentacija antigena se vrši molekula glavnih komoleksa tkivne histokompatibilnosti kompleksa tkivne histokompatibilnosti $(M H C)$ ili antigena humanih leukocita $(H L A)$ prisutnih na površini $A P C$-a i prepoznatih od virus specifičnih citotoksičnih T limfocita (CTL). Postoje dve glavne klase $M H C$-a koje su uključene u prezentaciju antigena: MHC I i MHC II, ali SARS-KoV virusi uglavnom aktiviraju klasu $M H C I$. Nažalost, nedostaju dokazi u vezi sa prezentacijom antigena u KOVID-19 infekciji, te je, za sada, većina zaključaka izvedena iz prethodnih studija rađenih na SARS-KoV i MERS-KoV virusima. Studije su takođe pokazale da različiti $H L A$ genotipovi mogu biti odgovorni za razlike u osetljivosti domaćina na virus, a prema tome, i za razlike $u$ težini bolesti. Pokazalo se da pacijenti zaraženi SARS-KoV virusom sa genotipovima $H L A-B$ 46:01 imaju težu formu bolesti, u poređenju sa onima sa drugim genotipovima. To još uvek nije klinički potvrđeno u studijama koje analiziraju SARS-KoV-2 virus [9].

Nakon antigenske prezentacije $u$ epitelnim ćelijama gornjeg, a potom i donjeg dela respiratornog the host cell. The most prevalent membrane protein, the $M$ protein, is, together with the $E$ protein, responsible for the coronavirus membrane structure. The $\mathrm{N}$ protein, which is a part of the RNA chain, is a component of the spiral nucleocapsid [5]. Binding and entry into the host cell is carried out with the help of the S protein, which is composed of two subunits. The S1 subunit is the receptor-binding segment, while the $\mathrm{S} 2$ subunit is considered to be the potential site where the antiviral drugs act. The target binding site for the SARS-CoV- 2 virus is the receptor for the angiotensin-converting enzyme 2 (ACE2), which can be found in different organs and cells, including the nasopharynx, the nasal and oral mucosa, the small intestine, the large intestine, the kidneys, the liver, the vascular endothelium and the epithelial cells of pulmonary alveoli (mainly type 2 pneumocytes) [6].

Previous studies have shown that the sensitivity of the host to the SARS-CoV-2 infection is, most probably, as in SARS-CoV, determined by the affinity between the ACE2 receptors of the host and the receptor-binding segment of the virus. It is believed that genetic recombination in the receptor-binding region of the $\mathrm{S}$ protein may be the cause of the virus's higher transmission rate, as compared with other coronaviruses [7]. After entering the cell, viral DNA is released, then $S, M$ and $E$ proteins are synthetized, as well as the nucleocapsid, and the new viral particle is formed, exiting the cell through exocytosis $[8,9]$. During the replication process, the SARS-CoV-2 virus has a high ability of correcting mutations that may occur, which is why it is believed that the mutation rate in this virus is lower than in other RNA viruses [6] (Image 1).

\section{Immune response to infection}

After the virus enters the body through the nasopharynx, antigen-presenting cells (APC), such as dendritic cells and macrophages, are activated. This leads to further activation of humoral and cell immunity, mediated by virus-specific $B$ and $T$ lymphocytes $[9,10]$. Antigen presentation is carried out by the major histocompatibility complexes (MHC) or human leukocyte antigens (HLA), present on the surface of the APC and recognized by the virus-specific cytotoxic $T$ lymphocytes (CTL). There are two main classes of $\mathrm{MHC}$ involved in antigen presentation: MHC class I and MHC class II, however, SARS-CoV viruses mainly activate MHC class I. Unfortunately, proof is missing in relation to antigen presentation in the COVID-19 infection, which is why, until now, most conclusions have been drawn on the basis of previous studies related to SARS-CoV and MERS-CoV viruses. Studies have also shown that different HLA genotypes may be responsible for the differences in host sensitivity to the virus, and thereby, for the differences in the severity of the illness. It has been noted that patients infected by the SARS-CoV virus with HLA-B 46:01 genotypes have 
(1) SARS-CoV-2 binding to ACE2 receptor and viral entry

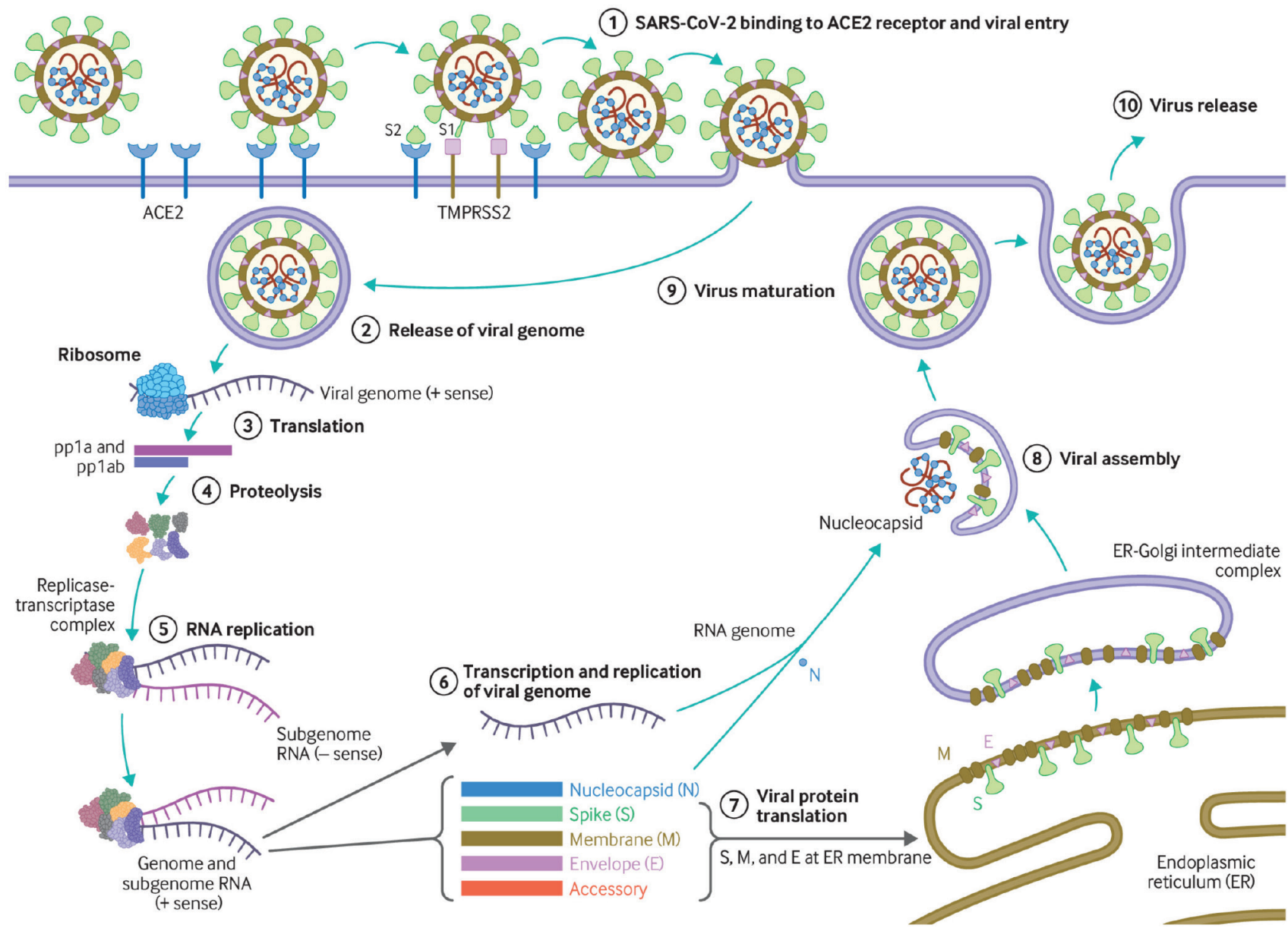

(1) Vezivanje SARS-KoV-2 za ACE2 receptor i ulazak virusa; (2) Oslobađanje virusnog genoma; (3)Translacija; (4)Proteoliza; (5) RNK replikacija; (6) Transkripcija i replikacija virusnog genoma; (7) Translacija virusnih proteina; (8) Formiranje virusa; (9) Sazrevanje virusa; (10) 0slobađanje virusa.

\section{Slika 1. Ciklus patogeneze virusa SARS-KoV-2}

Preuzeto sa: https://www.bmj.com/content/371/bmj.m3862.long (Cevik M, Kuppalli K, Kindrachuk J, Peiris. Virology, transmission, and pathogenesis of SARS-CoV-2. BMJ. 2020,371.) "This article is made freely available for use in accordance with BMJ's website terms and conditions for the duration of the covid-19 pandemic or until otherwise determined by BMJ. You may use, download and print the article for any lawful, non-commercial purpose (including text and data mining) provided that all copyright notices and trade marks are retained. https://bmj.com/coronavirus/usage"

trakta, dolazi do aktivacije CD4+ T ćelija, poznatih i kao pomoćničke $T$ ćelije, koje potom oslobađaju različite vrste citokina i hemokina. Ovo dovodi do mobilizacije i infiltracije makrofaga, monocita, limfocita i neutrofila u plućno tkivo, što pojačava dalju aktivaciju imunskog odgovora putem mehanizma pozitivne povratne sprege. SARS-KoV-2 virus može u veoma kratkom periodu da aktivira Th1 ćelije da luče proinflamatorne citokine, poput faktora stimulacije granulocitih kolonija (GMCSF) i interleukina-6 (IL-6). GM-CSF dalje aktivira CD14+ i CD16+ monocite, koji proizvode velike količine IL-6, tumor faktor nekroze-a (TNF-a) i drugih citokina [11]. Ukoliko dođe do nekontrolisane aktivacije ovih ćelija, može se razviti sindrom citokinske oluje.

Sindrom citokinske oluje i ranije je opisivan kod virusnih infekcija, uključujući SARS-KoV, MERS, viruse gripa $[12,13]$. Radovi Ruana i saradnika, kao i Huanga

\section{Figure 1. The SARS-CoV-2 virus pathogenesis cycle}

From:https://www.bmj.com/content/371/bmj.m3862.long (Cevik M, Kuppalli K, Kindrachuk J, Peiris. Virology, transmission, and pathogenesis of SARS-CoV-2. BMJ. 2020, 371.)

"This article is made freely available for use in accordance with BMJ's website terms and conditions for the duration of the covid-19 pandemic or until otherwise determined by BMJ. You may use, download and print the article for any lawful, non-commercial purpose (including text and data mining) provided that all copyright notices and trade marks are retained. https://bmj.com/coronavirus/usage"

a more severe form of the disease, as compared to other genotypes. This has, as yet, not been clinically confirmed in studies related to the SARS-CoV-2 virus [9].

After antigen presentation in the epithelial cells of the upper and then the lower respiratory tract, the activation of CD4+ T cells, also known as T-helper cells, occurs, after which these cells release different types of cytokines and chemokines. This leads to mobilization and infiltration of macrophages, monocytes, lymphocytes and neutrophils into the pulmonary tissue, which intensifies further activation of the immune response through the positive feedback mechanism. The SARS-CoV-2 virus can, in a very short time, activate Th1 cells to secrete proinflammatory cytokines, such as the granulocyte-macrophage colony-stimulating factor and interleukin-6 (IL-6). GM-CSF further activates CD14+ and CD16+ monocytes, which produce large 
i saradnika, pokazuju da su kritično oboleli pacijenti, lečeni $u$ jedinici intenzivne nege, imali značajno više sistemske nivoe IL-6, IL-2, IL-7, IL-10, GM-CSF-a, monocitnog hemoaktivnog proteina-1 $(M C P-1)$, makrofagnog inflamatornog proteina-1A (MIP-1A), i tumorskog faktora nekroze a (TNF- $a)$, u odnosu na pacijente sa lakšim formama bolesti. Najznačajniji među ovim citokinima je IL-6 [14,15]. Za njegovu produkciju je zadužen širok spektar imunih ćelija, kao što su makrofagi, neutrofili, dendritične ćelije i limfociti. Međutim, veoma je važan podatak da i strukturne ćelije oštećenog tkiva, koje ne pripadaju imunološkom spektru, kao što su mezenhimske ćelije, endotelne ćelije i fibroblasti, takođe imaju sposobnost produkcije ovog citokina.

Još jedan razlog povećane produkcije proinflamatornih parametara je blokiranje $A C E 2$ receptora u plućnom tkivu, koje za posledicu ima smanjenje proizvodnje $A C E 2$, a posledično i povećanje nivoa angiotenzina 2, što dovodi do lokalnog povećanja krvnog pritiska i hiperinflamacije. Nakon proizvodnje, IL-6, putem krvotoka, dolazi u jetru i brzo aktivira hepatocite da proizvode C-reaktivni protein, serumski amiloid A i fibrinogen. IL-6 dovodi do diferencijacije naivnih CD4+T ćelija u efektorske i pomoćničke ćelije, potom do aktivacije i diferencijacije citotoksičnih CD8+ T limfocita, koji dalje produkuju proinflamatorne markere, čime se stvara „začarani krug" inflamacije [16,17].

I dalje je izazov razumeti zašto neki pacijenti razviju ovako snažan imunski odgovor, dok drugi ne. Jedno od objašnjenja je da genetski polimorfizmi, kao što su promene u strukturi toll-like receptora $(T L R)$, mogu doprineti slaboj indukciji interferona- $\gamma($ IFN- $\gamma)$, koji je deo antiinflamatornog imunskog odgovora, čime se podstiče proinflamacija i nadalje razvoj citokinske oluje [18].

Značajna posledica citokinske oluje je akutno difuzno oštećenje pluća, uključujući težak oblik ARDS-a. Takođe, s obzirom na to da se virus vezuje i za ostale ACE2 receptore $u$ organizmu, dolazi do oštećenja bubrega, srca, creva, jetre, a kako se ovi receptori nalaze i na endotelu kapilara, dolazi do pojave sistemskog vaskulitisa. Nakon obdukcije pacijenata preminulih od KOVID-19 infekcije, patohistološki je dokazan limfocitni endotelitis u tkivima pluća, srca, creva, bubrega, jetre kao i nekroza hepatocita [19].

\section{KLINIČKA SLIKA}

\section{Simptomi bolesti}

Klinički simptomi se najčešće javljaju između četvrtog i petog dana od izlaganja virusu, međutim, studije su pokazale da period inkubacije može trajati do 14 dana [20]. Najčešći simptomi zabeleženi u dosadašnjoj literaturi uključuju povišenu telesnu temperaturu, kašalj, umor i otežano disanje, koji su slični drugim virusnim quantities of IL-6, the tumor necrosis factor-a (TNF-a), and other cytokines [11]. If uncontrolled activation of these cells occurs, cytokine storm syndrome may develop.

Cytokine storm syndrome has previously been described in viral infections, including SARS-CoV, MERS, flu viruses [12,13]. Studies by Ruan et al. and Huang et al. have shown that critically ill patients, treated in the intensive care unit, had significantly higher systemic levels of IL-6, IL-2, IL-7, IL-10, GM-CSF, monocyte chemoattractant protein-1 (MCP-1), macrophage inflammatory protein-1A (MIP-1A), and tumor necrosis factor a (TNF-a), as compared to patients with milder forms of the disease. The most significant amongst these cytokines is IL-6 [14,15]. A wide array of immune cells is responsible for its production, such as macrophages, neutrophils, dendritic cells, and lymphocytes. However, it is very important to note that structural cells which do not belong to the immunological spectrum, such as mesenchymal cells, endothelial cells, and fibroblasts, also have the ability to produce this cytokine.

Another reason for increased production of proinflammatory parameters is the blocking of ACE2 receptors in the pulmonary tissue, which results in the reduction of ACE2 production, and, consequently, in the increase of the level of angiotensin 2, which leads to the increase in blood pressure and to hyperinflammation. After production, IL-6, through the bloodstream, reaches the liver and quickly activates hepatocytes to produce C-reactive protein, serum amyloid A, and fibrinogen. IL- 6 leads to the differentiation of naive CD4+ T cells into effector and helper cells, then to the activation and differentiation of cytotoxic CD8+ T lymphocytes, which further produce proinflammatory markers, thereby closing the'vicious cycle' of inflammation $[16,17]$.

Understanding why some patients develop such a strong immune response while others do not, remains a challenge to understand. One of the explanations is that genetic polymorphisms, such as changes in the structure of toll-like receptors (TLR), may contribute to a weak induction of interferon- $\gamma$ (IFN- $\gamma)$, which is a part of the anti-inflammatory immune response, whereby proinflammation and further development of the cytokine storm is stimulated [18].

A significant effect of the cytokine storm is acute diffuse lung injury, including a severe form of ARDS. In addition, since the virus also binds to other ACE2 receptors in the body, damage to the kidneys, heart, intestines and liver, occurs as well, and, since these receptors are also located on the capillary endothelium, systemic vasculitis develops. After autopsies of COVID-19 victims, lymphocytic endotheliitis in lung, cardiac, intestinal, renal and hepatic tissue has pathohistologically been proven, as well as hepatocyte necrosis [19]. 
infekcijama, uključujući sezonski grip. Studija Bhatrajua i saradnika identifikovala je 24 kritično obolela pacijenta iz devet bolnica u okolini Sijetla kod kojih je laboratorijski potvrđena infekcija KOVID-19, sa simptomima koji su započeli $7 \pm 4$ dana pre prijema. Najčešći prijavljeni simptomi su bili kašalj i otežano disanje, a oko $50 \%$ pacijenata imalo je povišenu telesnu temperaturu pri prijemu [21]. Studija iz Njujorka, epicentra pandemije u Sjedinjenim Američkim Državama (SAD), koja je obuhvatila 5.700 pacijenata sa infekcijom KOVID-19, otkrila je da je 30,7\% pacijenata bilo febrilno pri prijemu [22]. Velika studija u Kini, koja je obuhvatala 1.099 pacijenata sa laboratorijski potvrđenom KOVID-19 infekcijom, pokazala je da je 43,8\% pacijenata imalo povišenu telesnu temperaturu pri prijemu, dok je $88,7 \%$ pacijenata razvilo temperaturu tokom boravka u bolnici. Drugi najčešće prijavljeni simptom bio je kašalj (67,8\%), dok je manje pacijenata prijavilo gastrointestinalne simptome, kao što su mučnina (5\%) i dijareja (3,8\%) [20]. Anosmija i disgeuzija se takođe javljaju kod pacijenata sa SARS-KoV-2 virusom i najčešće prethode pojavi ostalih simptoma [23].

$\mathrm{O}$ asimptomatskoj infekciji se takođe govori u literaturi, međutim, njena učestalost ostaje nejasna. Studija na 55 asimptomatskih nosilaca potvrđene infekcije SARS-KoV-2, prilikom prijema, otkrila je da je većina ovih pacijenata, na kraju, ipak imala blage simptome, dok je asimptomatska infekcija bila retka i uglavnom se javljala kod mladih pacijenata, starosti između 18 i 29 godina [24]. Druga studija, u kojoj je učestvovalo 634 pacijenta zaraženih KOVID-19 infekcijom na brodu za krstarenje u Japanu, otkrila je da je 17,9\% njih bilo bez simptoma [25].

\section{Oblici bolesti}

Prema Nacionalnom protokolu Republike Srbije za lečenje KOVID-19 infekcije [26], klinički oblici KOVID-19 oboljenja su sledeći:

1. Asimptomatski oblik

2. Blaga klinička slika (bolesnici sa blagim kliničkim simptomima, bez potrebe za kiseoničnom potporom, bez komorbiditeta, bez radiografski verifikovane pneumonije)

3. Umereno teška klinička slika (teška hipoksija sa potrebom za oksigenom terapijom, febrilnost, multiple opacifikacije na radiografiji pluća ili specifične promene na plućima viđene na skeneru grudnog koša, citokinska oluja koja podrazumeva pogoršanje opšteg stanja uz skok vrednosti CRP, fibrinogena, D-dimera, IL-6 - skok bar jednog od ovih parametra)

4. Veoma teška/teška klinička slika (citokinska oluja uz početak ili razvoj ARDS-a)

\section{CLINICAL PRESENTATION}

\section{Symptoms of the disease}

Clinical symptoms most commonly occur between the fourth and the fifth day of exposure to the virus, however, studies have shown that the incubation period may last up to 14 days [20]. The most common symptoms registered in literature, so far, include elevated body temperature, cough, fatigue and labored breathing, similar to those in other viral infections, including seasonal flu. A study by Bhatraju et al. identified 24 critically ill patients from nine hospitals in the Seattle suburban area, who were confirmed to have the COVID-19 infection through laboratory tests, and whose symptoms had begun $7 \pm 4$ days prior to admission. The most commonly reported symptoms were coughing and labored breathing, and around $50 \%$ of the patients had elevated body temperature at admission [21]. A study from New York, the epicenter of the pandemic in the United States of America (USA), which included 5,700 patients with the COVID-19 infection, discovered that $30.7 \%$ of the patients were febrile at admission [22]. A large study in China, which included 1,099 patients with the COVID-19 infection confirmed via laboratory tests, showed that $43.8 \%$ of the patients had elevated body temperature at admission, while $88.7 \%$ of the patients developed a fever during their stay in hospital. The second most commonly reported symptom was coughing $(67.8 \%)$, while fewer patients reported gastrointestinal symptoms such as nausea (5\%) and diarrhea (3.8\%) [20]. Anosmia and dysgeusia also occur in SARS-CoV-2 patients and most commonly precede the onset of other symptoms [23].

Asymptomatic infection is also discussed in literature; however, its frequency remains unclear. A study on 55 asymptomatic carriers of confirmed SARS-CoV-2 infection, at admission, revealed that most of these patients did experience mild symptoms eventually, while asymptomatic infection was rare and occurred mainly in young patients, aged between 18 and 29 years [24]. A different study, which included 634 patients infected with COVID-19, on a cruise ship in Japan, discovered that $17.9 \%$ of them were asymptomatic [25].

\section{Forms of the disease}

According to the National Protocol of the Republic of Serbia for the Treatment of the COVID-19 Infection [26], the clinical forms of the COVID-19 disease are, as follows: 1. Asymptomatic form

2. Mild clinical presentation (patients with mild clinical symptoms, without the need for supplemental oxygen, without comorbidities, without radiographically confirmed pneumonia)

3. Moderate clinical presentation (severe hypoxia with the need for oxygen therapy, febrility, multiple 


\section{Faktori rizika za nastanak komplikacija}

Studije su pokazale da postoje brojni faktori rizika koji utiču na klinički tok bolesti. Vu i saradnici su pokazali da je među 44.672 slučajeva KOVID-19 infekcije u Vuhanu, u Kini, najviše bilo pacijenata starosti od 30 do 79 godina $(87 \%)$, potom onih od 80 godina i starijih (3\%), dok je samo $1 \%$ pacijenata bilo starosti 9 godina i mlađe [27]. Starija dob bila je jedan od identifikovanih faktora rizika koji je povezan sa lošom prognozom i smrću [28]. Što se tiče pola, ostaje nejasno da li je on nezavisan faktor rizika za ozbiljnije forme bolesti.

Retrospektivnom analizom 393 pacijenta sa potvrđenom KOVID-19 infekcijom utvrđeno je da je 60,6\% ovih pacijenata bilo muškog pola. Takođe, muškarci su češće bili na mehaničkoj ventilaciji u odnosu na žene [29]. Studija Guana i saradnika pokazala je da su pacijenti sa teškom formom češće imali neku pridruženu bolest, u poređenju sa onima sa lakšim formama bolesti (38,7\% naspram 21\%) [20]. Druga studija rađena u Vuhanu, u Kini, pokazala je da je od 191 pacijenta sa KOVID-19 infekcijom, hipertenzija (30\%) bila najčešći komorbiditet, praćen dijabetesom (19\%), koronarnom bolešću ( $8 \%$ ) i hroničnom opstruktivnom bolešću pluća (3\%) [28]. Prema podacima Centra za kontrolu bolesti i prevenciju (CDC) u SAD-u, među 7.162 pacijenta, najčešće prijavljeni komorbiditeti bili su dijabetes melitus $(10,9 \%)$, hronična bolest pluća $(9,2 \%)$, kardiovaskularne bolesti (9,0\%), i hronična bolest bubrega (3,7\%) [30]. U studiji iz Njujorka, koja je obuhvatila 5.700 pacijenata sa infekcijom KOVID-19, najčešći komorbiditeti kod hospitalizovanih pacijenata bili su hipertenzija $(56,6 \%)$, gojaznost $(41,7 \%)$ i dijabetes $(33,8 \%)$ [31]. U retrospektivnoj kohortnoj studiji na 124 pacijenta inficiranih SARSKoV-2 virusom, utvrđeno je da je gojaznost faktor rizika za intubaciju. Od pacijenata koji su bili intubirani, 47,6\% je imalo indeks telesne mase (engl. body mass index $B M I)>30 \mathrm{~kg} / \mathrm{m} 2$, a 28,2\% je imalo $B M I>35 \mathrm{~kg} / \mathrm{m} 2$ [32].

U kliničkoj praksi se pokazalo da različita imunokompromitujuća stanja utiču na razvoj teške forme bolesti i dugotrajno izlučivanje virusa kod pacijenata sa KOVID-19 infekcijom. Prikazan je slučaj pacijenta sa Brutonovom agamaglobulinemijom lečenog u Klinici za infektivne i tropske bolesti Univerzitetskog kliničkog centra Srbije, kod kojeg je, u periodu od pet nedelja, u dva navrata došlo do razvoja teške bilateralne pneumonije, što je objašnjeno relapsom bolesti, koji je dokazan održavanjem pozitivnosti reakcije lančane polimerizacije $(R T-P C R)$ nazofaringealnog brisa na SARS-KoV-2 tokom navedenog perioda, uz nemogućnost razvoja antitela [33]. Takođe je prikazan slučaj pacijentkinje obolele od Nehočkinovog limfoma, koja je tokom 12 nedelja izlučivala SARS-KoV-2 virus, te su autori ovog rada postavili hipotezu o potencijalnom opacities visible on radiographic images of the lungs or characteristic lesions in the lungs visible on chest CT images, cytokine storm resulting in the deterioration of the general status of the patient, and a spike in the level of CRP, fibrinogen, D-dimer, or IL-6 - a spike in at least one of the parameters)

4. Very severe/severe clinical presentation (cytokine storm with onset or development of ARDS)

\section{Risk factors for the development of complications}

Studies have shown that there are numerous risk factors affecting the clinical course of the disease. In a study on 44,672 cases of COVID-19 infection in Wuhan, in China, Wu et al. demonstrated that the majority of patients were aged between 30 and 79 years (87\%), followed by patients aged 80 years and older (3\%), while only $1 \%$ of patients were aged 9 years or younger [27]. Older age was one of the identified risk factors connected to an unfavorable prognosis and death [28]. As to sex, it remains unclear whether it is an independent predictor of the severe form of the disease.

A retrospective analysis of 393 patients with confirmed COVID-19 infection determined that $60,6 \%$ of them were men. Also, men were more often on mechanical ventilation, as compared to women [29]. A study by Guan et al. showed that patients with a severe form of the disease more commonly had a comorbidity, as compared to those with a milder form (38.7\% vs. 21\%) [20]. Another study carried out in Wuhan, China, showed that, out of 191 patients with the COVID-19 infection, hypertension was the most common comorbidity (30\%), followed by diabetes (19\%), coronary disease (8\%), and chronic obstructive pulmonary disease (3\%) [28]. According to the data of the Center for Disease Control and Prevention (CDC) in USA, in a group of 7,162 patients, the most commonly reported comorbidities were diabetes mellitus (10.9\%), chronic pulmonary disease $(9.2 \%)$, cardiovascular diseases $(9.0 \%)$, and chronic kidney disease (3.7\%) [30]. In a study from New York, which included 5,700 patients with the COVID-19 infection, the most common comorbidities in hospitalized patients were hypertension (56.6\%), obesity (41.7\%), and diabetes (33.8\%) [31]. It was determined that obesity was a risk factor for intubation in a retrospective cohort study including 124 patients infected with the SARS-CoV-2 virus. Of the intubated patients, $47.6 \%$ had a body mass index $(\mathrm{BMI})>30 \mathrm{~kg} / \mathrm{m} 2$, while $28.2 \%$ had a $\mathrm{BMl}>35 \mathrm{~kg} / \mathrm{m} 2$ [32].

Clinical practice has shown that different immunocompromising conditions affect the development of the severe form of the disease and prolonged excretion of the virus in patients with the COVID-19 infection. The case of a patient with Bruton agammaglobulinemia, treated at the Clinic for Infectious and Tropical Diseases of the University Clinical Center of Serbia was reported, 
postojanju hronične KOVID-19 infekcije kod imunokompromitovanih pacijenata [34].

\section{Komplikacije bolesti}

Veoma su česte komplikacije KOVID-19 infekcije, čija je učestalost različita u do sada objavljenim studijama. Studija u kojoj je učestvovalo 138 pacijenata iz Vuhana, u Kini [35] pokazala je da je 19,6\% pacijenata razvilo ARDS. Druge česte komplikacije identifikovane u ovoj studiji bile su septički šok (8,7\%), aritmija (16,7\%) i akutna srčana insuficijencija (7,2\%). Komplikacije su bile češće kod pacijenata lečenih $u$ jedinicama intenzivne nege [35]. Druga studija koja je obuhvatila 191 pacijenta iz Vuhana, u Kini, pokazala je da je najčešća komplikacija bila sepsa (59\%), praćena respiratornom insuficijencijom (54\%), ARDS-om (31\%), srčanom insuficijencijom (23\%) i septičkim šokom (20\%).

Ostale, ređe komplikacije bile su koagulopatija, definisana kao produženje aktiviranog parcijalnog tromboplastinskog vremena u trajanju od 5 sekundi ili produženje protrombinskog vremena u trajanju od 3 sekunde (19\%), kao i akutna koronarna bolest (17\%). Srčani događaji, poput razvoja ili pogoršanja postojeće kongestivne srčane insuficijencije, infarkta miokarda, aritmije i srčanog zastoja, češće su se javljali kod pacijenata sa pridruženom upalom pluća [28].

Kod teške forme bolesti dolazi do pojave hiperkoagulabilnosti, koja je podstaknuta disfunkcijom endotelnih ćelija usled endotelitisa, kao i povećanim viskozitetom krvi usled hipoksije [36,37]. Akutna venska tromboembolija (VTE) zabeležena je kod pacijenata sa SARS-KoV-2. Holandska studija, koja je obuhvatila 184 pacijenta lečenih $u$ jedinici intenzivnog lečenja sa dokazanom KOVID-19 infekcijom, otkrila je 31\% učestalosti trombotičkih komplikacija, od kojih se $27 \%$ sastojalo od radiografski potvrđene venske tromboembolije. Plućna embolija (PE) bila je najčešća od ovih trombotičkih komplikacija [38]. Druga studija, u Vuhanu, u Kini, pokazala je da je 66 od 143 hospitalizovana pacijenta sa KOVID-19 oboljenjem razvilo trombozu dubokih vena (engl. deep vein thrombosis - DVT) donjih ekstremiteta. Njihova analiza sugeriše višestruke uzroke DVT-a kod ovih pacijenata, uključujući starije životno doba, težu formu bolesti, udružene hronične bolesti [39]. Akutna bubrežna insuficijencija (ABI) je komplikacija koja se, prema dosadašnjim podacima, javlja sa učestalošću od $0,5 \%$ do $80 \%$. Patofiziološki, može nastati usled prerenalne azotemije kao posledice hipovolemije, potom usled vaskulitisa i mikrotromboza zbog vezivanja virusa za ACE2 receptore, kao i zbog imunološkog oštećenja glomerula nakon oslobađanja citokina i interferona. Povezana je sa produženim trajanjem hospitalizacije i sa povećanom stopom mortaliteta osoba obolelih od KOVID-19 infekcije [40]. who, within a space of five weeks, developed severe bilateral pneumonia twice, which was explained with disease relapse, proven by a continued positive result of the reverse transcription polymerase chain reaction (RT-PCR) of the nasopharyngeal swab to the SARSCoV-2 virus during the above stated period of time, with the inability of antibody production [33]. A case of a patient suffering from non-Hodgkin lymphoma was also described. She excreted the COVID-19 virus for 12 weeks, and the authors of this study postulated the hypothesis of the potential existence of chronic SARSCoV-2 infection in immunocompromised patients [34].

\section{Disease complications}

Complications of the COVID-19 infection are very common. The frequency of these complications in studies published so far is variable. A study including 138 patients from Wuhan, in China [35] showed that 19.6\% of patients developed ARDS. Other frequent complications identified in this study include septic shock (8.7\%), arrythmia (16.7\%), and acute heart failure (7.2\%). Complications were more common in patients treated in intensive care units [35]. A different study, including 191 patients from Wuhan, China, showed that the most common complication was sepsis (59\%), followed by respiratory insufficiency (54\%), ARDS (31\%), heart failure (23\%), and septic shock (20\%).

Other, less common complications of the disease were coagulopathy, defined as the prolongation of activated partial thromboplastin time by 5 seconds or the prolongation of prothrombin time by 3 seconds $(19 \%)$, as well as acute coronary disease (17\%). Cardiac events, such as the development or deterioration of existing congestive heart failure, myocardial infarction, arrhythmia, and cardiac arrest, more commonly occurred in patients with associated pneumonia [28].

In the severe form of the disease hypercoagulability occurs, stimulated by the dysfunction of endothelial cells caused by endotheliitis, as well as by increased viscosity of the blood caused by hypoxia [36,37]. Acute venous thromboembolism (VTE) was registered in patients with the SARS-CoV-2. A Dutch study, including 184 patients with proven COVID-19 infection treated in the intensive care unit, discovered a $31 \%$ frequency of thrombotic complications, of which $27 \%$ consisted of radiographically confirmed venous thromboembolism. Pulmonary embolism (PE) was the most common amongst these thrombotic complications [38]. Another study in Wuhan, China, showed that 66 out of 143 hospitalized patients suffering from COVID-19 developed deep vein thrombosis (DVT) of the lower extremities. Their analysis suggests multiple causes of DVT in these patients, including older age, a more severe form of the disease, associated chronic diseases [39]. Acute 


\section{DIJAGNOZA}

\section{Mikrobiološke i serološke metode}

U respiratornom traktu, SARS-KoV-2 se može detektovati u trenutku pojave simptoma ili u prvoj nedelji bolesti, sa naknadnim smanjenjem mogućnosti detekcije nakon toga, što ukazuje na najveći potencijal zaraznosti neposredno pre ili u prvih pet dana od pojave simptoma, za razliku od SARS-KoV-1 i MERS virusa, čiji je najveći virusni nivo u drugoj nedelji bolesti [41].

Metoda detekcije, koja predstavlja zlatni standard za dijagnozu SARS-KoV-2 virusa je RT-PCR test iz nazofaringealnog brisa [42]. Do lažno negativnog nalaza $R T$-PCR testiranja na SARS-KoV-2 može doći zbog nedovoljne količine virusa, kada se uzorak prerano ili prekasno uzme u toku bolesti, kao i zbog tehničkih grešaka prilikom rukovanja ili slanja materijala. Lažno negativni nalazi se, prema podacima iz literature, javljaju u minimalno $23 \%$ do $30 \%$ slučajeva, dok se lažno pozitivni nalazi RT-PCR testiranja javljaju u maksimalno $2 \%$ do $5 \%$ slučajeva [43]. Uzorci bronhoalveolarnog lavaža donjih disajnih puteva (BAL) verovatnije će dati pozitivan rezultat nego uzorci gornjih disajnih puteva. U studiji koja je obuhvatila 205 pacijenata, 93\% uzoraka BAL-a (14 od 15) bilo je pozitivno, u poređenju sa $72 \%$ uzorka nazofaringealnog brisa (72 od 104) [44]. Shodno tome, ako je početno testiranje negativno, ali klinička sumnja i dalje ostaje visoka, SZO preporučuje ponavljanje ispitivanja, po mogućnosti na uzorku donjih disajnih puteva [2].

Što se tiče seroloških testova, nivoi lgM i lgG antitela postaju detektabilni najčešće između desetog i četrnaestog dana bolesti, održavaju se približno mesec dana, potom im koncentracija u serumu opada, najverovatnije tokom dužeg vremenskog perioda. Treba napomenuti da se nivo IgM antitela u serumu značajno smanjuje nakon šest nedelja od pojave simptoma [45]. Serološki testovi su nepouzdani za dijagnostiku i korisni su samo za seroepidemiološka ispitivanja. Otkrivanje virusnih proteina i lgA antitela u sluzokoži je takođe veoma važno. Zapravo, ovi markeri se povećavaju u ranim fazama infekcije i mogu se koristiti za ranu dijagnozu infekcije KOVID-19 [46]. U poređenju sa metodama zasnovanim na $R T-P C R$ analizi, brze antigenske i brze testove na antitela karakterišu: brža izrada testa (od 1530 minuta), niži troškovi, kao i lakši postupak, koji ne zahteva prisustvo visoko obučenog osoblja. Ovi testovi su uglavnom zasnivaju na principu imunoeseja (engl. lateral-flow immunoassay - LFIA) za direktno otkrivanje virusnih proteina (brzi testovi antigena) ili humanih antitela protiv SARS-KoV-2 antigena (brzi testovi antitela). Testovi su pozitivni od samog početka bolesti i njihova pozitivnost se održava tokom prvih nekoliko dana od pojave prvih tegoba, ali negativni testovi, ukoliko postoji klinička sumnja, zahtevaju RT-PCR potvrdu [47]. renal failure (ARF) is a complication which, according to data so far, occurs at a frequency ranging from $0.5 \%$ to $80 \%$ of cases. Pathophysiologically, ARF can occur due to prerenal azotemia caused by hypovolemia, also due to vasculitis and microthromboses resulting from the virus binding to ACE2 receptors, as well as due to immunological damage to the glomeruli after the release of cytokines and interferon. ARF is connected to the prolonged effect of hospitalization and to the increased mortality rate of SARS-CoV-2 patients [40].

\section{DIAGNOSIS}

\section{Microbiology and serology methods}

In the respiratory tract, SARS-CoV-2 can be detected at the moment of symptom onset or in the first week of illness, with the possibility of detection subsequently decreasing, which indicates the highest infective potential of the virus immediately prior to or within the first five days of the onset of symptoms, as opposed to SARS-CoV-1 and MERS viruses, whose greatest viral level is in the second week of the disease [41].

The method of detection, which represents the golden standard for diagnosing the SARS-CoV-2 virus is the RT-PCR nasopharyngeal swab test [42]. A false-negative RT-PCR test result for SARS-CoV-2 may occur due to an insufficient quantity of the virus, if the sample is taken too soon or too late in the course of the illness, or due to technical errors in the handling or transportation of the material. According to data found in literature, false-negative results occur at least in $23 \%$ to $30 \%$ of the cases, while false-positive RT-PCR test findings occur in no more than $2 \%$ to $5 \%$ of the cases [43]. Samples of bronchoalveolar lavage (BAL) of lower respiratory airways are more likely to produce a positive result than upper respiratory tract samples. In a study covering 205 patients, $93 \%$ of BAL samples (14 out of 15) were positive, as compared to $72 \%$ of the nasopharyngeal swab samples (72 out of 104) [44]. Therefore, if initial testing is negative, but the clinical suspicion remains high, the WHO recommends retesting, if possible, on a sample taken from the lower respiratory tract [2].

Regarding serological tests, the levels of $\operatorname{lgM}$ and IgG antibodies typically become detectible between day 10 and day 14 of the disease; they persist approximately for a month, after which their concentration in the serum drops, probably over a longer period of time. It should be noted that the level if IgM antibodies in the serum significantly decreases six weeks after the onset of symptoms [45]. Serological tests are unreliable for diagnostic purposes and are useful only for seroepidemiological studies. Detecting viral proteins and $\lg A$ antibodies in the mucosa is also very important. In fact, these markers increase in the early phases of infection and can be used for early diagnosis of the COVID-19 infection 
Mikrobiološke metode koje se kod nas koriste $u$ svakodnevnoj praksi su RT-PCR, brzi antigenski i serološki testovi, dok u svetu postoje i alternativne metode dijagnostikovanja SARS-KoV-2, kao što je kultura virusa, nova generacija sekvenciranja genoma (engl. next-generation-sequencing - NGS), koja koristi nanotehnologiju identifikacije genoma virusa $[48,49]$. Takođe se koriste metode ispitivanja izotermičkog pojačanja posredstvom petlje (engl. loop-mediated isothermal amplification - LAMP), koje su među najčešće korišćenim alternativnim metodama amplifikacije nukleinske kiseline za dijagnozu zaraznih bolesti. U slučaju SARS-KoV-2, do sada je razvijeno nekoliko ovakvih sistema [50]. Takođe je moguća i detekcija virusa u stolici pacijenata obolelih od SARS-KoV-2. Ova metoda daje pozitivan rezultat krajem druge nedelje bolesti, a mogućnost detekcije opada nakon šeste nedelje [51] (Slika 2).
[46]. As compared to methods based on RT-PCR analysis, rapid antigen and rapid antibody tests are characterized by the following: quick completion of the test $(15-30$ minutes), lower cost, a simpler procedure that does not require the presence of highly trained staff. These tests are mainly based on the principle of the immunoassay (lateral-flow immunoassay - LFIA) for direct detection of viral proteins (rapid antigen tests) or human antibodies against the SARS-CoV-2 antigen (rapid antibody tests). Tests are positive from the very onset of disease and their positivity is maintained over the first few days following the onset of symptoms, but negative tests, if clinical suspicion exists, require RT-PCR confirmation [47].

Microbiology methods used in Serbia in everyday practice are the RT-PCR test, rapid antigen and rapid serological tests, while, internationally, alternative methods of diagnosing the SARS-CoV-2 are also applied, such as viral culture, next-generation sequencing - NGS, which uses nanotechnology for viral
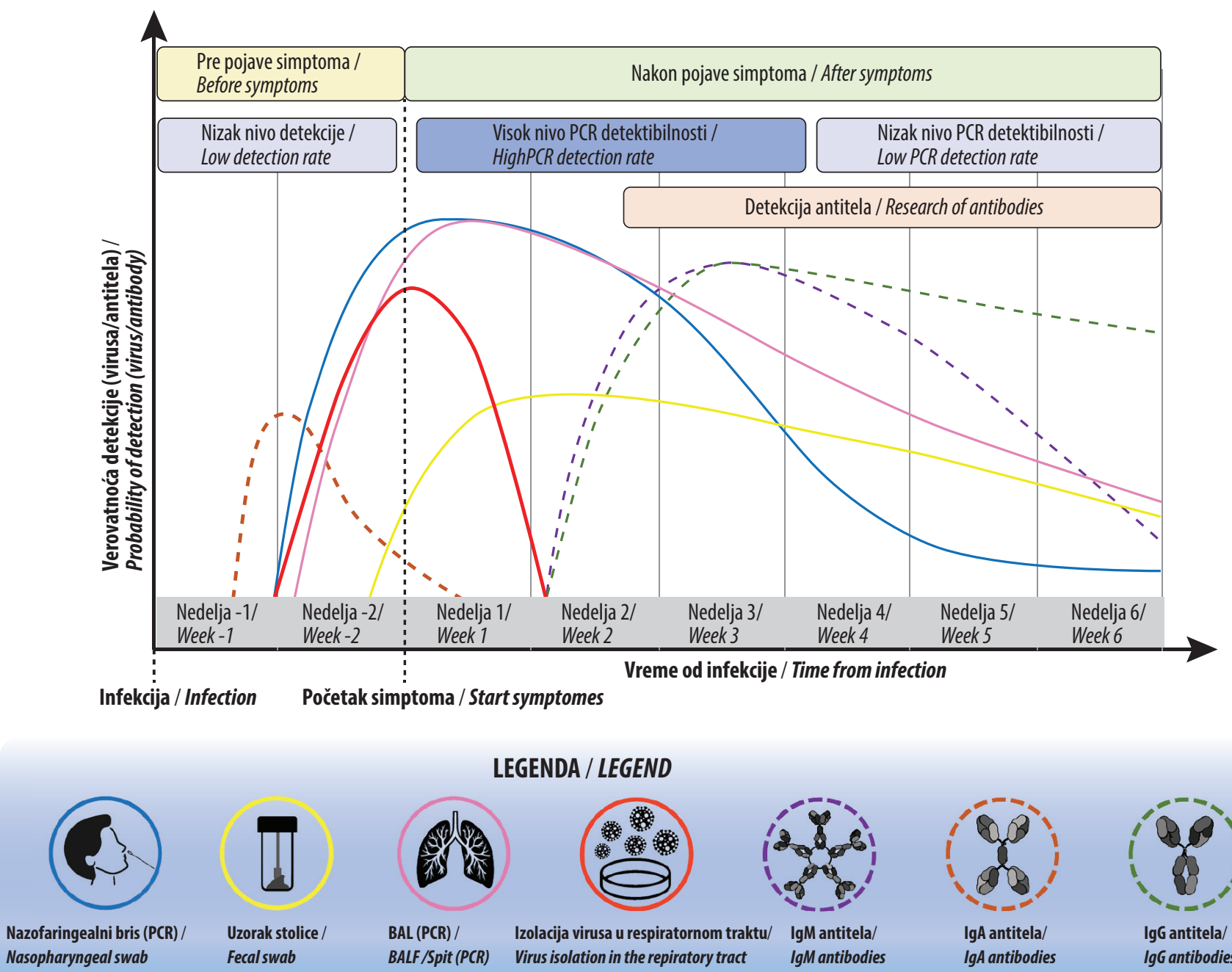

LEGENDA / LEGEND

\section{Slika 2. Načini detektovanja SARS-KoV-2 virusa}

Preuzeto sa: https://doi.org/10.3892/ijmm.2021.4933. (Falzone L, Gattuso G, Tsatsakis A, Spandidos DA, Libra M. Current and innovative methods for the diagnosis of COVID 19 infection (Review). Int J Mol Med. 2021 Jun;47(6):100)
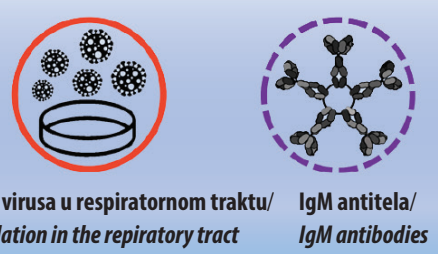
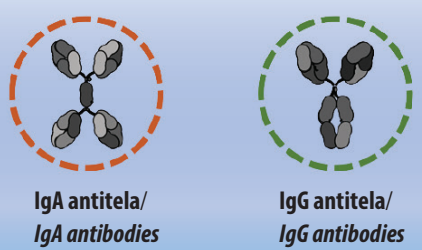

Figure 2. Methods of SARS-CoV-2 virus detection

From: https://doi.org/10.3892/ijmm.2021.4933. (Falzone L, Gattuso G, Tsatsakis A, Spandidos DA, Libra M. Current and innovative methods for the diagnosis of COVID 19 infection (Review). Int J Mol Med. 2021 Jun;47(6):100) 


\section{Laboratorijske analize}

Utvrđeno je da hospitalizovani pacijenti sa infekcijom SARS-KoV-2 imaju različit broj belih krvnih zrnaca. Studija Huanga i saradnika pokazala je leukopeniju $(<4 \times 109 / \mathrm{L})$ kod $25 \%$ pacijenata, normalan broj leukocita (4 - $10 \times 109 /$ L) kod 45\% pacijenata, i leukocitozu (> $10 \times 109 / \mathrm{L}$ ) kod 30\% pacijenata. Limfopenija $(<1 \times 109 / L)$ je pronađena kod 63\% pacijenata [52]. Još jedna studija Guana i saradnika je pokazala da je leukopenija bila prisutna kod 33,7\% pacijenata na prijemu, dok je 36,2\% slučajeva imalo trombocitopeniju [20]. U sistematskom pregledu i metaanalizi 43 studije, u kojima je učestvovalo 3.600 pacijenata, najčešće laboratorijske abnormalnosti uključivale su povišeni C-reaktivni protein $(68,6 \%)$, limfopeniju $(57,4 \%)$ i povišenu laktat dehidrogenazu (LDH) (51,6\%) [53]. Studija koju su sproveli Zhou i saradnici pokazala je pozitivnu korelaciju povišenih nivoa LDH, serumskog feritina, IL-6 i srčanog troponina I, sa pogoršanjem bolesti i mortalitetom [28].

Brojne studije pokazale su da se kod velikog broja pacijenata javlja poremećaj koagulacije. U velikoj retrospektivnoj studiji na 1.099 pacijenata sa potvrđenom KOVID-19 infekcijom u Kini, zaključeno je da su se povišene vrednosti D-dimera javljale češće kod pacijenata sa težim formama bolesti [54]. U drugoj, takođe retrospektivnoj studiji na 183 pacijenta sa potvrđenom KOVID-19 infekcijom u Vuhanu, utvrđeno je da su preminuli pacijenti imali značajno veće nivoe proizvoda razgradnje fibrina, među kojima je i D-dimer, kao i produženo protrombinsko vreme (PV) pri prijemu, u poređenju sa preživelim pacijentima. Nivoi fibrinogena i antitrombina (AT) takođe su bili značajno niži kod preminulih pacijenata. Kod 71,4\% preminulih dijagnostikovana je diseminovana intravaskularna koagulacija (DIK) tokom hospitalizacije, dok se DIK među preživelim pacijentima javila u 0,6\% slučajeva. Rezultati ukazuju na to da su abnormalni parametri koagulacije tokom KOVID-19 pneumonije bili značajno povezani sa lošom prognozom bolesti [55]. Studije su takođe pokazale da se nivo azotnih materija, odnosno kreatinina i uree u krvi, progresivno povećava kod kritično bolesnih pacijenata [56].

\section{Radiološka dijagnostika \\ 3.1 Kompjuterizovana tomografija (CT) grudnog koša}

Karakteristične promene na CT pregledu grudnog koša tokom ranih faza KOVID-19 infekcije obično su periferne i fokalne ili multifokalne promene tipa „mlečnog stakla“, koje se javljaju kod približno 50 75\% pacijenata. Kako bolest napreduje, takozvano „popločavanje“ (engl. 'crazy paving') i konsolidacije postaju dominantni nalazi CT-a, dostižući vrhunac oko 9 - 13. dana, nakon čega sledi postepeno genome detection [48,49]. Also in use are the methods of loop-mediated isothermal amplification (LAMP), which are amongst the most commonly applied methods of amplifying nucleic acid for the diagnosis of infectious diseases. In the case of SARS-CoV-2 infection, several such systems have so far been developed [50]. The detection of the virus in the stool of patients suffering from the SARS-CoV-2 is also possible. This method yields a positive result at the end of the second week of the disease, while the possibility of detection drops after the sixth week [51] (Figure 2).

\section{Laboratory analyses}

It has been determined that the leukocyte count in hospitalized patients with the SARS-CoV-2 infection varies. A study by Huang et al. showed leukopenia $(<4 \times 109 / \mathrm{L})$ in $25 \%$ of the patients, a normal white blood cell count $(4-10 \times 109 / \mathrm{L})$ in $45 \%$ of the patients, and leukocytosis (> $10 \times 109 / \mathrm{L})$ in $30 \%$ of the patients. Lymphopenia $(<1 \times 109 / L)$ was found in $63 \%$ of the patients [52]. Another study by Guan et al. showed that leukopenia was present in $33.7 \%$ of the patients at admission, while $36.2 \%$ of the cases had thrombocytopenia [20]. In a systematic review and meta-analysis of 43 studies, which involved 3,600 patients, the most frequent laboratory abnormalities included elevated C-reactive protein (68.6\%), lymphopenia (57.4\%), and elevated lactate dehydrogenase (LDH) (51.6\%) [53]. A study by Zhou et al. showed a positive correlation between elevated levels of LDH, serum ferritin, IL- 6 and cardiac troponin I, and disease exacerbation and mortality [28].

Numerous studies have shown that, in a large number of patients, coagulation disruption occurs. In a large retrospective study on 1,099 patients with confirmed COVID-19 infection, in China, it was concluded that increased values of D-dimer occured more frequently in patients with more severe forms of the disease [54]. In a another, also retrospective study, on 183 patients with confirmed COVID-19 infection, in Wuhan, it was noted that deceased patients had significantly higher levels of fibrin degradation products, including D-dimer, as well as a prolonged prothrombin time (PT) at admission, as compared to surviving patients. The levels of fibrinogen and antithrombin (AT) were also significantly lower in deceased patients. In $71.4 \%$ of the deceased patients, disseminated intravascular coagulation (DIC) was diagnosed during hospitalization, while DIC occurred in $0.6 \%$ of the surviving patients. The results indicate that abnormal coagulation parameters during COVID-19 pneumonia were significantly linked to a poor prognosis of the outcome of the disease [55]. Studies have also shown that the level of nitrous matters, i.e., creatinine and urea, progressively increase in critically ill patients [56]. 
povlačenje promena, koje traje više od mesec dana. Do $50 \%$ pacijenata sa infekcijom KOVID-19 može imati normalan CT nalaz grudnog koša do drugog dana nakon pojave simptoma [57]. S druge strane, pokazalo se da se promene na CT-u grudnog koša tipične za KOVID-19 infekciju mogu razviti kod asimptomatskih pacijenata [58]. Huang i saradnici su objavili studiju u kojoj su svi hospitalizovani pacijenti imali neke od CT karakteristika KOVID-19 pneumonije u barem jednom delu plućnih polja, dok je 98\% (40 od 41) pacijenata imalo obostranu zahvaćenost pluća [52].

\subsection{Radiografija (RTG) grudnog koša}

Radiografski pregled grudnog koša je široko dostupan i stvara manji rizik od zračenja u poređenju sa CT-om. Međutim, neke studije su pokazale da RTG grudnog koša možda nema osetljivost za otkrivanje nekih plućnih promena koje se često vide u KOVID-19 pneumonijama, a koje se inače otkrivaju CT-om. Slično CT-u, najčešći patološki nalaz na RTG-u grudnog koša kod KOVID-19 pneumonije podrazumeva pojavu difuzno raspoređenih promena denziteta "mlečnog stakla" i konsolidacija plućnog parenhima [59].

\section{TERAPIJA}

Prema Nacionalnom protokolu Republike Srbije za lečenje KOVID-19 infekcije, u Srbiji se, u lečenju ovog oboljenja, koriste sledeći lekovi [26]:

1. Antivirusni lekovi (favipiravir i remdesivir), koje je najefikasnije dati u prvih pet do sedam dana od početka pojave tegoba jer je njihov cilj sprečavanje replikacije virusa.

2. Preporuka Svetske zdravstvene organizacije je protiv primene remdesivira, a Američko udruženje za infektivne bolesti (engl. Infectious Disease Society of America - IDSA) preporučuje primenu ovog leka samo kod teških formi oboljenja koje zahtevaju terapiju kiseonikom, ali ne i kod pacijenata koji su na mehaničkoj ventilaciji.

3. Kortikosteroidna terapija, koja se primenjuje nakon četvrtog dana bolesti kod pacijenata obolelih od oblika 3, 4 i 5, u cilju sprečavanja citokinske oluje; primenjuju se prednizon, metilprednizolon i deksametazon.

4. Imunomodulatorna terapija - tocilizumab, koji se primenjuje kod pacijenata obolelih od oblika 3, 4 i 5 , u slučaju da, nakon prethodno primenjenih terapijskih mera, i dalje progredira nalaz na plućima i rastu vrednosti parametara zapaljenja, kako bi se sprečila citokinska oluja.

5. Imunoglobulini, koji se primenjuju kod teških formi bolesti sa nedostatkom ili smanjenom koncentracijom imunoglobulina.

\section{Radiological diagnostics}

\subsection{Computerized tomography (CT) of the chest}

Characteristic changes found on chest CT scans in the early stages of the COVID-19 infection usually present as peripheral and focal or multifocal ground glass opacities, occurring in approximately $50-75 \%$ patients. As the disease progresses, so called 'crazy paving' occurs and consolidations become the dominant CT finding, peaking between day 9 and day 13, upon which gradual subsiding of the changes occurs, lasting over a month. Up to $50 \%$ of patients with the COVID-19 infection may have a normal chest CT finding up to the second day after symptom onset [57]. On the other hand, it has been noted that changes visible on chest CT scans typical of the COVID-19 infection may develop in asymptomatic patients [58]. Huang et al. published a study where all hospitalized patients had some of the CT characteristics of COVID-19 pneumonia in at least some of the lung fields, while $98 \%$ (40 out of 41) of the patients had bilateral changes in the lungs [52].

\subsection{Radiography (RTG) of the chest}

Radiographic examination, i.e., X-ray of the chest is widely available and poses a lesser radiation exposure risk than $\mathrm{CT}$. However, some studies have shown that the chest X-ray may not have the sensitivity to detect certain pulmonary changes, often found in COVID-19 pneumonia, which are easily detected on a CT scan. As in the CT scan, the most frequent pathological chest X-ray finding in COVID-19 pneumonia is the occurrence of diffusely distributed ground glass opacities and pulmonary consolidations [59].

\section{TREATMENT}

According to the National Protocol of the Republic of Serbia for the Treatment of the COVID-19 Infection, the following drugs are being used in Serbia in the treatment of this disease [26]:

1. Antiviral drugs (favipiravir and remdesivir), which are most effective within the first five to seven days of symptom onset, as their purpose is to prevent the replication of the virus.

2. The recommendation of the World Health Organization is against the use of remdesivir, while the Infectious Disease Society of America (IDSA) recommends the use of this drug only in severe forms of the disease where oxygen therapy is necessary, but not in patients on mechanical ventilation.

3. Corticosteroid therapy, applied after day 4 of disease onset in patients suffering from forms 3,4 and 5 of the disease, for the purpose of preventing cytokine storm; prednisone, methylprednisolone and dexamethasone are applied. 
6. Plazma rekonvalescenata se daje kod pacijenata kod kojih je došlo do progresivnog pogoršanja stanja, a kod kojih nije prošlo više od dve nedelje od početka bolesti. Iskustvo sa Mejo klinike je pokazalo da plazmu treba dati u prva tri dana i pod uslovom da postoji značajan titar anti SARS-KoV-2 antitela.

7. Neutrališuća monklonska antitela (bamlanivimab), koja se vezuju za S protein i efikasna su kod pacijenata koji su pod povećanim rizikom za pojavu teške forme KOVID-19 (BMI $\geq 35$, hronično oboljenje bubrega, dijabetes, imunosupresivno oboljenje/ stanje, $\geq 65$ godina, $\geq 55$ godina i pridruženo kardiovaskularno oboljenje ili hipertenziju ili hroničnu opstruktivnu bolest pluća/drugo teško respiratorno oboljenje); daje se isključivo u ranim fazama bolesti.

8. Antikoagulantni lekovi - niskomolekularni heparin u profilaktičkim dozama se primenjuje kod svih hospitalizovanih pacijenata, dok se terapijske doze preporučuju kod pacijenata sa sumnjom na razvoj ili sa potvrđenom venskom trombozom.

9. Vitaminska terapija, koja podrazumeva primenu vitamin C i alfakalcidiola.

10.Antibiotska terapija, koja se isključivo daje kod pacijenata sa verovatnom ili dokazanom bakterijskom superinfekcijom (Tabela 1).

Pored navedenih lekova, koji se koriste kod nas, u svetu se u lečenju SARS-KoV-2 infekcije primenjuju i hlorokin/hidroksihlorokin (lek se primenjivao kod nas, ali nije dokazana njegova efikasnost), ivermektin (Centrar za kontrolu bolesti $(C D C)$, Američko udruženje za infektivne bolesti (IDSA) ne savetuju da se koristi, osim u okviru odobrenih studija), lopinavir/ritonavir, azitromicin, druga neutrališuća antitela (casirivimab/imdevimab i sotrovimab) $[1,60]$.

\section{VAKCINACIJA}

Početak pandemije i identifikacija SARS-KoV-2 virusa, pokrenula je naučne institucije širom sveta da proizvedu efikasnu vakcinu. Početkom decembra 2020. godine počela je vakcinacija u SAD i Velikoj Britaniji, potom krajem decembra i u Evropi, kada je započela i vakcinacija u Srbiji. Do sada je u svetu ukupno vakcinisano 3,0 milijarde ljudi, od čega je 834 miliona kompletno vakcinisanih, što čini $10,7 \%$ ukupno vakcinisane svetske populacije, dok je u Srbiji do sada vakcinisano 5,15 miliona stanovnika od čega potpuno 2,45 miliona, što predstavlja 35,3\% populacije Srbije [61].

Vakcine koje se primenjuju u Srbiji su:

1. Sputnik V (Gam-COVID-Vac) je vektorska vakcina u kojoj je rekombinantni adenovirus izmenjen tako da se ne umnožava, a zapravo je prenosilac gena
4. Immunomodulatory therapy - tocilizumab, which is applied in patients suffering from forms 3,4 and 5 of the disease, in cases where, after previously applied therapeutic measures, the pulmonary findings are still deteriorating and the inflammation parameters continue to grow, in order to prevent cytokine storm.

5. Immunoglobulins, applied in severe forms of the disease where there is a lack of or a decrease in the concentrations of immunoglobulins.

6. Convalescent plasma is given to patients whose condition has progressively deteriorated, and in whom two weeks have as yet not elapsed from the onset of disease. Experience from the Mayo Clinic has shown that plasma needs to be administered in the first three days and under the proviso that there is a significant titer of SARS-CoV-2 antibodies.

7. Neutralizing monoclonal antibodies (bamlanivimab), which bind to the $\mathrm{S}$ protein and are effective in patients who are at increased risk of developing the severe form of COVID-19 (BMI $\geq 35$, chronic kidney disease, diabetes, immunosuppressive disease/state, $\geq 65$ years, $\geq 55$ years with associated cardiovascular disease or hypertension or chronic obstructive pulmonary disease/other severe respiratory disease); administered only in the early stages of the disease.

8. Anticoagulant drugs - low-molecular-weight heparin in prophylactic doses is applied in all hospitalized patients, while therapeutic doses are recommended in patients with suspected or confirmed development of venous thrombosis.

9. Vitamin therapy, includes the application of vitamin C and alphacalcidol.

10. Antibiotic therapy, which is applied only in patients with likely or proven bacterial superinfection (Table 1).

In addition to the drugs listed above, which are being used in Serbia, in other countries, other drugs are also used in treating the SARS-CoV-2 infection. These include: chloroquine/hydroxychloroquine (the drug was applied in Serbia, but its effectiveness was not proven), ivermectin (the US Center for Disease Control (CDC) and the Infectious Disease Society of America (IDSA) do not recommend using this drug, except in approved studies), lopinavir/ritonavir, azithromycin, other neutralizing antibodies (casirivimab/imdevimab and sotrovimab) $[1,60]$.

\section{VACCINATION}

The beginning of the pandemic and the identification of the SARS-CoV-2 virus has incited scientific institutions all over the world to produce an effective vaccine. In early December 2020, vaccination started in USA and Great Britain, and subsequently, late in December of the same 


\begin{tabular}{|c|c|c|}
\hline FORMA BOLESTI & USTANOVA & TERAPIJA \\
\hline $\begin{array}{l}\qquad \text { OBLIK } 1 \\
\text { 1. Pozitivan nazofaringealni bris } \\
\text { (PCR na SARS-KoV-2, Ag test) } \\
\text { 2. Asimptomatska } \\
\text { 3. Vrlo blaga klinička slika } \\
\text { 4. Bolesnici bez komorbiditeta i sa blagim oblikom } \\
\text { infekcije (hospitalizovani pacijenti } \mathrm{sa}_{\mathrm{s}} \mathrm{O}_{2}>4 \% \text { i bez } \\
\text { Rtg znakova pneumonije }\end{array}$ & $\begin{array}{l}\text { Kućno lečenje i izolacija uz kontrole i } \\
\text { nadzor Kovid ambulanti }\end{array}$ & $\begin{array}{l}\text { Vitaminska th: alfakalcidol tbl. (Alpha D3) 1×2 mcg, vitamin C } \\
\text { 1x1g (ukoliko nema bubrežnih smetnji) } \\
\text { *Ne davati antibiotike rutinski! Zbog rizika ozbiljnih neželjenih } \\
\text { dejstava i rastuće rezistencije na antimikrobne lekove. } \\
\text { Antivirusna th. (započeti najkasnije do 5. dana od početka } \\
\text { tegoba): } \\
\text { Favipiravir tbl. } 100 \mathrm{mg} \text { na } 12 \mathrm{~h} \text {, prvi dan, zatim } 600 \mathrm{mg} \text { na } 12 \mathrm{~h} \text { još } \\
4 \text { dana (lek se primenjuje kod obolelih koji imaju simptome) } \\
\text { Simptomatska th. }\end{array}$ \\
\hline $\begin{array}{l}\qquad \text { OBLIK } 2 \\
\text { 1. Pozitivan nazofaringealni bris } \\
\text { (PCR na SARS-KoV-2, Ag test) } \\
\text { 2. Blaga klinička slika } \\
\text { 3. Bolesnici bez komorbiditeta i sa blagim oblikom } \\
\text { infekcije (hospitalizovani pacijenti sa } \mathrm{SO}_{2}>94 \% \text { i sa } \\
\text { Rtg znacima pneumonije sa ili bez znakova } \\
\text { hipoksije pri prijemu) }\end{array}$ & $\begin{array}{l}\text { 1. Kovid centri: odelj. Opšteg tipa } \\
\text { 2. Opšte bolnice: odelj. izolacije } \\
\text { Mere pojačanog nadzora } \\
\text { Više puta dnevno praćenje temperature, } \\
\mathrm{SO}_{2} \text { i fr. disanja }\end{array}$ & $\begin{array}{l}\text { Antikoagulantna th: Niskomolekularni heparin } \\
\text { Antivirusna th. (započeti najkasnije do 5. dana od početka } \\
\text { tegoba): } \\
\text { Favipiravir tbl. } 1600 \mathrm{mg} \text { na } 12 \mathrm{~h} \text {, prvi dan, zatim } 600 \mathrm{mg} \text { na } 12 \mathrm{~h} \\
\text { još } 4 \text { dana } \\
\text { Kortikosteroidna th. } \\
\text { Vitaminska th: alfakalcidol tbl. (Alpha D3) } 1 \times 2 \mathrm{mcg} \text {, vitamin C1x1g } \\
\text { Plazma rekonvalescenata (unutar } 2 \text { nedelje od početka tegoba i } \\
\text { nakon konsultacije sa infektologom i transfuziologom, prema skoru) } \\
\text { Primena antibiotika samo kod verovatne ili dokazane bakterijske inf! }\end{array}$ \\
\hline $\begin{array}{l}\qquad \text { OBLIK } 3 \\
\text { 1. Pozitivan nazofaringealni bris } \\
\text { (PCR na SARS-KoV-2, Ag test) } \\
\text { 2. Umereno teška klinička slika } \\
\text { 3. Teška hipoksija sa potrebom za oksigenu } \\
\mathrm{Th}\left(\mathrm{s}_{2}<94 \%\right) \text {, febrilnost, multiple opacifikacije } \\
\text { na Rtg u pluća (ili specifične promene na plućima } \\
\text { viđene na (T-u) } \\
\text { 4. Citokinska oluja (pogoršanje opšteg stanja uz } \\
\uparrow(R P, \uparrow \text { fibrinogen, } \uparrow \mathrm{D} \text {-dimer, } \uparrow \text { IL-6) (bar jednog } \\
\text { parametra) }\end{array}$ & $\begin{array}{l}\text { 1. Kovid centri: odelj. poluintenzivne } \\
\text { nege } \\
\text { 2. Opšte bolnice: odelj. izolacije sa } \\
\text { stalnim nadzorom ( } \leq 1 \mathrm{~h} \text { ) inteziviste, } \\
\text { anesteziologa), infektologa ili } \\
\text { interniste } \\
\text { 3. U slučaju daljeg pogoršanja: } \\
\text { transport u Kovid intenzivne nege }\end{array}$ & $\begin{array}{l}\text { Antikoagulantna th: Niskomolekularni heparin } \\
\text { Vitaminska th: alfakalcidol tbl. (Alpha D3) 1x2 mcg, vitamin } \\
\text { C 1 1x1g } \\
\text { Oksigenoterapija: nazalni kateter ili maska (0210-15 L/min) } \\
\text { Antivirusna th. (ako je prošlo manje od 5. dana od početka } \\
\text { tegoba) Favipiravir (kao gore) ili Remdesivir amp. } 200 \mathrm{mg} \text { i.v. } \\
\text { prvi dan, zatim } 100 \mathrm{mg} \text { i.v./dan još } 4 \text { dana } \\
\text { Kortikosteroidna th. } \mathrm{i} / \text { /ili tocilizumab } 8 \mathrm{mg} / \mathrm{kg} \text { i.v. po dozi. } \\
\text { Daju se } 2 \text { doze (max. } 800 \mathrm{mg} / \text { dozi) } \\
\text { Antibiotska th: prema vodiču za racionalnu primenu antibiotika, } \\
\text { Plazma rekonvalescenata (unutar } 2 \text { nedelje od početka tegoba i } \\
\text { nakon konsultacije sa infektologom i transfuziologom, prema skoru) }\end{array}$ \\
\hline $\begin{array}{l}\qquad \text { OBLIK } 4 \text { i } 5 \\
\text { 1. Pozitivan nazofaringealni bris } \\
\text { 2. Veoma teška/teška klinička slika } \\
\text { 3. Početak ili razvoj ARDS-a } \\
\text { 4. Citokinska oluja (pogoršanje opšteg stanja uz } \\
\text { TCRP, } \uparrow \text { fibrinogen, } \uparrow D-\text { dimer, } \uparrow I L-6 \text { ) }\end{array}$ & Kovid centri: intenzivna nega & $\begin{array}{l}\text { Primeniti sve dostupne mere/ kombinacije intenzivnog lečenja } \\
\text { 1. Što duže održavanje na } \uparrow \text { protoku } \mathbf{O}_{2^{\prime}} \text { MV u slučaju pogorša- } \\
\text { nja } \\
\text { 2. Kortikosteroidna th: Metilprednizolon } 1-2 \mathrm{mg} / \mathrm{kg}, 3-5 \text { dana, } \\
\text { a zatim postupno redukovanje doze (dozu prilagoditi telesnoj } \\
\text { masi da bi se smanjio rizik krvarenja i drugih neželjenih efekata) } \\
\text { 3. Tocilizumab: } 8 \mathrm{mg} / \mathrm{kg} \text { i.v. po dozi - } 2 \text { doze (max. } 800 \mathrm{mg} / \text { dozi) } \\
\text { 4. Imunoglobulni: } 10-20 \mathrm{~g} / \text { dan Ig tokom } 3-5 \text { dana }\end{array}$ \\
\hline
\end{tabular}

Tabela 1. Protokol za lečenje KOVID-19 infekcije

Prilagođeno iz: NacioanIni vodič Republike Srbije za lečenje COVID-19 infekcije (Verzija 11)

koji omogućava stvaranje S proteina, koji podstiče stvaranje imunološkog odgovora. Prva i druga doza vakcine se primaju u razmaku od tri nedelje, a razlikuju se samo u odnosu na nosač (adenovirus serotip 26 u prvoj, odnosno serotip 5 u drugoj dozi). Prema zasad dostupnim podacima, nakon 1 - 4 nedelje od primljene druge doze vakcine, stvara se imunitet koji je efikasan oko $92 \%$ u sprečavanju infekcije a $100 \%$ protiv teškog oblika bolesti KOVID-19 [62].

2. Pfizer-BioNTech vakcina sadrži informacionu RNK year, vaccination began in Europe as well, which is when it also started in Serbia. Thus far, a total of 3.0 billion people in the world have been vaccinated, of which 834 million have received complete vaccination, which makes up for $10.7 \%$ of vaccinated population in the world, while, in Serbia, 5.15 million citizens have been vaccinated so far, of which 2.45 million have been fully vaccinated, which makes up for $35.3 \%$ of the nation's population [61].

The vaccines administered in Serbia are the following: 


\section{PROTOCOL FOR THE TREATMENT OF COVID-19 PATIENTS}

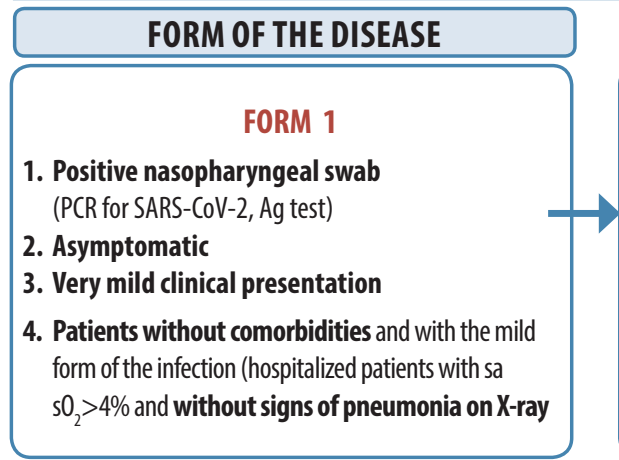

FORM 2

1. Positive nasopharyngeal swab (PCR for SARS-CoV-2, Ag test)

2. Mild clinical presentation

3. Patients without comorbidities and with the mild form of the infection (hospitalized patients with $\mathrm{sO}_{2}>94 \%$ and with signs of pneumonia on X-ray, but without signs of hypoxia at admission)

\section{INSTITUTION}
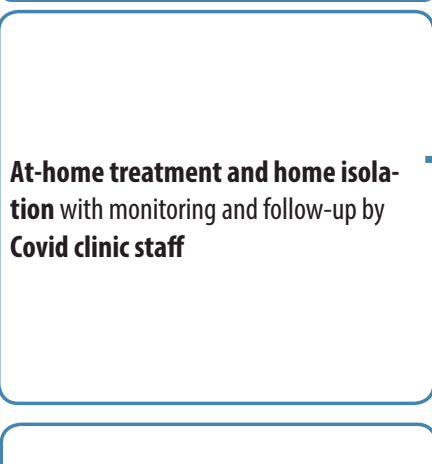

. Covid centers: general wards

2. General hospitals: isolation units

Increased monitoring measures Checking patient temperature, $\mathrm{SO}_{2}$ and respiration rate several times a day

1. Covid centers: semi-intensive care

2. General hospitals: isolation units

3. In case of further deterioration $\left(\mathrm{SO}_{2}<94 \%\right)$, fever, multiple opacities on chest X-ray (or units with constant monitoring ( $\leq 1 \mathrm{~h})$ of intensive care specialist, anesthesiologist, infectologist or internal medicine specialist transportation to Covid intensive

care

\section{TREATMENT} day of symptom onset): with symptoms)

Symptomatic treatment day of symptom onset): $\mathrm{mg}$ every $12 \mathrm{~h}$ for another 4 days

Corticosteroid therapy vitamin $1 \times 1 \mathrm{~g}$ ding to the score) status with $\uparrow$ CRP, $\uparrow$ fibrinogen, $\uparrow \mathrm{D}$-dimer, $\uparrow \mathrm{IL}-6$ (at least one parameter elevated)

1. Positive nasopharyngeal swab

Moderate clinical presentation characteristic changes in the lungs visible on (T)

-

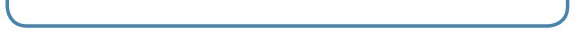

FORM 4 i 5

1. Positive nasopharyngeal swab

2. Very severe/severe clinical presentation

3. Onset or development of ARDS

4. Cytokine storm (deterioration of general health status with $\uparrow(\mathrm{RP}, \uparrow$ fibrinogen, $\uparrow \mathrm{D}$-dimer, $\uparrow$ IL-6)
Covid centers: intensive care units

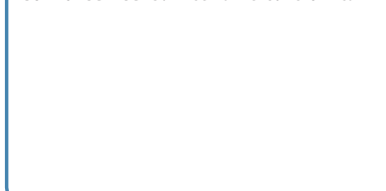

Vitamin therapy: alphacalcidol tablets (Alpha D3) 1×2 mcg, vitamin C 1x1g (if there are no kidney issues)

*Do not routinely prescribe antibiotics due to the risk of serious adverse effects and the rising resistance to antimicrobial drugs) Antiviral therapy ((to be introduced no later than the $5^{\text {th }}$

favipiravir tablets, 1,600 mg every $12 \mathrm{~h}$ on the first day, then 600 $\mathrm{mg}$ every $12 \mathrm{~h}$ for another 4 days (the drug is applied in patients

Anticoagulant therapy: low-molecular-weight heparin Antiviral therapy ((to be introduced no later than the $5^{\text {th }}$

favipiravir tablets, $1,600 \mathrm{mg}$ every $12 \mathrm{~h}$ on the first day, then 600

Vitamin therapy: alphacalcidol tablets (Alpha D3) $1 \times 2 \mathrm{mcg}$,

Convalescent plasma: (within 2 weeks of symptom onset and after consultation with an infectologist and transfusiologist, accor-

Application of antibiotics only in likely or proven bacterial infection

Anticoagulant therapy: low-molecular-weight heparin
Vitamin therapy: alphacalcidol tablets (Alpha D3), $1 \times 2 \mathrm{mcg}$,
vitamin C $1 \times 1 \mathrm{~g}$
Oxygen therapy: nasal catheter or mask $\mathrm{O}_{2}$ ( 10 - $15 \mathrm{I} /$ minute
Antiviral therapy (if less than 5 days have elapsed since symptom
onset): favipiravir (as above) or remdesivir ampules $200 \mathrm{mg}$ intra-
venously on the first day, then $100 \mathrm{mg}$ IV/day for another 4 days
(Corticosteroid therapy and/or tocilizumab $8 \mathrm{mg} / \mathrm{kg}$ IV per dose.
Two doses are administered (max $800 \mathrm{mg}$ per dose)
Antibiotic therapy: in keeping with the guidelines for rational
application of antibiotics
Convalescent plasma: (within 2 weeks of symptom onset and after
consultation with an infectologist and transfusiologist, according to
the score)

All available measures/combinations of measures need to be applied

1. Maintaining $\uparrow \mathbf{O}_{2}$ flow as long as possible, MV in case of further deterioration

2. Corticosteroid therapy: methylprednisolone $1-2 \mathrm{mg} / \mathrm{kg}$, 3-5 days, then gradual reducing of the dose (dose should be adjusted to body mass in order to reduce the risk of bleeding and other adverse effects)

3. Tocilizumab: $8 \mathrm{mg} / \mathrm{kg} \mathrm{IV}$ per dose. Two doses ( $\mathrm{max} 800 \mathrm{mg}$ per dose)

4. Immunoglobulins: $10-20 \mathrm{~g}$ per day Ig over a period of $3-5$ days

Table 1. Protocol for the treatment of the COVID-19 infection

Adapted from: Protocol of the Republic of Serbia for the Treatment of the COVID-19 Infection (Version 11)

(iRNK) u lipidnom omotaču koji omogućava stvaranje $S$ proteina u ćelijama i tako dovodi do stvaranja zaštitnog imuniteta. Važno je napomenuti da se iRNK ne umnožava i ne ugrađuje u genom ćelije jer se brzo razgrađuje u organizmu. Vakcinacija se sprovodi u dve odvojene doze vakcine, u razmaku
1. The Sputnik V (Gam-COVID-Vac) is a vector vaccine in which the recombinant adenovirus is altered in such a way that it does not multiply, and is, in fact, the carrier of the gene that enables the production of the $S$ protein, which stimulates the creation of the immunological response. The first and second dose of the vaccine 
od najmanje 3 nedelje, kod osoba uzrasta 16 godina i starijih. Prema zasad dostupnim podacima, nakon 1 - 4 nedelje od primljene druge doze vakcine, stvara se imunitet koji je efikasan 95\% [63].

3. Sinopharm je inaktivisana vakcina proizvedena tehnologijom prethodno već korišćenom u razvoju vakcina (npr. vakcina protiv dečije paralize, besnila). Vakcina sadrži inaktivisani virus SARS-KoV-2 koji je izgubio sposobnost umnožavanja, ali zato stvara zaštitni imunitet. Sprovodi se kroz dve odvojene doze vakcine, u razmaku od 2 - 4 nedelje. Nema publikovanih podataka u naučnoj literaturi, ali prema zasad dostupnim podacima iz Kine, nakon 1 - 4 nedelje od primljene druge doze vakcine, stvara se imunitet koji je efikasan oko 80\% [64].

4. AstraZeneca KOVID-19 vakcina je takođe vektorska vakcina u kojoj je rekombinantni adenovirus (poreklom od šimpanze) nosač za gen koji omogućava stvaranje $S$ proteina i dovodi do stvaranja zaštitnog imuniteta. Prema zasad dostupnim podacima, nakon 1 - 4 nedelje od primljene druge doze vakcine, stvara se imunitet koji je efikasan 60 - 90\% [65].

Za sada se sve vakcine primenjuju u populaciji odraslih. $U$ toku su studije na većem broju ispitanika koje treba da obezbede više podataka o delotvornosti vakcina.

\section{ZAKLJUČAK}

S obzirom na to da pandemija još uvek traje, potrebno je da i dalje širimo saznanja iz ove oblasti kao i da motivišemo ljude na vakcinaciju, jer je ona, za sada, jedini način da se zaustavi transmisija virusa. Takođe je potrebno da u naučnim krugovima delimo svoja znanja i iskustva iz ove pandemije, jer, s obzirom na veliku genetsku raznolikost koronavirusa i čestu rekombinaciju njihovih genoma, uz interakciju čoveka i životinja, novi koronavirusi će se verovatno i dalje razvijati i uzrokovati periodična sezonska širenja.

Sukob interesa: Nije prijavljen. are given within the space of three weeks, and they differ amongst themselves only as to the carrier (adenovirus serotype 26 in the first, and the serotype 5 , in the second dose). According to the data available so far, $1-4$ weeks after the second dose is received, immunity is developed, which is $92 \%$ effective in preventing infection, and $100 \%$ effective in preventing the severe form of the COVID-19 disease [62].

2. The Pfizer-BioNTech vaccine contains messenger RNA (mRNA) in the lipid shell, which enables the production of the S protein in the cells, and, in this way, it leads to the development of protective immunity. It is important to note that mRNA does not replicate and does not become inserted in the cell's genome, as it quickly disintegrates in the body. Vaccination is executed in two separate doses of the vaccine, spaced at least three weeks, in patients 16 years and older. According to the data available so far, after 1 - 4 weeks of receiving the second dose of the vaccine, patients develop immunity which is $95 \%$ effective [63].

3. The Sinopharm vaccine is an inactivated vaccine, produced with technology previously employed in the development of vaccines (e.g., the polio vaccine, the rabies vaccine). The vaccine contains the inactivated SARS-CoV-2 virus, which has lost its ability to replicate, however, it creates protective immunity. Immunization is carried out through two separate doses of the vaccine, two to four weeks apart. There is no published data in scientific literature, but, according to data available from China so far, 1 - 4 weeks after the second dose, immunity is developed, which is $80 \%$ effective [64].

4. The AstraZeneca COVID-19 vaccine is also a vector vaccine in which the recombinant adenovirus (originating from a chimpanzee) is the carrier of a gene enabling the production of the S protein and leading to the development of protective immunity. According to data available so far, 1 - 4 weeks after receiving the second dose of the vaccine, the subject develops immunity, which is $60-90 \%$ effective [65].

For now, all vaccines are applied in the adult population. Studies on a larger number of subjects are ongoing and they should provide more data on the effectiveness of the vaccines.

\section{CONCLUSION}

Bearing in mind that the pandemic is still ongoing, it is necessary that we should further expand our knowledge in this area and continue to motivate people to get vaccinated, as vaccination, for now, remains the only way to stop the transmission of the virus. It is also necessary to share knowledge and experience from 


\section{LITERATURA / REFERENCES}

1. Chams N, Chams S, Badran R, Shams A, Araji A, Raad M, et al. COVID-19: A Multidisciplinary Review. Front Public Health. 2020 Jul 29;8:383.

2. WHO. Clinical management of COVID-19: living guidance. Jan 25, 2021. Geneva: World Health Organization, 2021.

3. Yan R, Zhang Y, Li Y, Xia L, Guo Y, Zhou Q. Structural basis for the recognition of SARS-CoV-2 by full-length human ACE2. Science. 2020 Mar 27;367(6485):1444-8.

4. Zhu N, Zhang D, Wang W, Li X, Yang B, Song J, et al; China Novel Coronavirus Investigating and Research Team. A Novel Coronavirus from Patients with Pneumonia in China, 2019. N Engl J Med. 2020 Feb 20;382(8):727-33.

5. Masters PS. The molecular biology of coronaviruses. Adv Virus Res. 2006, $66,193-292$.

6. Cevik M, Kuppalli K, Kindrachuk J, Peiris M. Virology, transmission, and pathogenesis of SARS-CoV-2. BMJ. 2020 0ct 23;371:m3862.

7. Shereen MA, Khan S, Kazmi A, Bashir N, Siddique R. COVID-19 infection: Origin, transmission, and characteristics of human coronaviruses. J Adv Res. 2020 Mar 16;24:91-8.

8. Cheng A, Zhang W, Xie Y, Jiang W, Arnold E, Sarafianos SG, et al. Expression, purification, and characterization of SARS coronavirus RNA polymerase. Virology. 2005 May 10;335(2):165-76.

9. Li X, Geng M, Peng Y, Meng L, Lu S. Molecular immune pathogenesis and diagnosis of COVID-19. J Pharm Anal. 2020 Apr;10(2):102-8.

10. Li G, Fan Y, Lai Y, Han T, Li Z, Zhou P, et al. Coronavirus infections and immune responses. J Med Virol. 2020 Apr;92(4):424-32.

11. Zhou Y, Fu B, Zheng X, Wang D, Zhao C, Qi Y, et al. Pathogenic T-cells and inflammatory monocytes incite inflammatory storms in severe COVID-19 patients. National Science Review. 2020, 7, 998-1002.

12. Mahallawi WH, Khabour OF, Zhang Q, Makhdoum HM, Suliman BA. MERSCoV infection in humans is associated with a pro-inflammatory Th1 and Th17 cytokine profile. Cytokine. 2018 Apr;104:8-13.

13. Wong CK, Lam CW, Wu AK, Ip WK, Lee NL, Chan IH, et al. Plasma inflammatory cytokines and chemokines in severe acute respiratory syndrome. Clin Exp Immunol. 2004 Apr;136(1):95-103.

14. Ruan $Q$, Yang K, Wang W, Jiang L, Song J. Clinical predictors of mortality due to COVID-19 based on an analysis of data of 150 patients from Wuhan, China. Intensive Care Med. 2020 May;46(5):846-8.

15. Huang C, Wang Y, Li X, Ren L, Zhao J, Hu Y, et al. Clinical features of patients infected with 2019 novel coronavirus in Wuhan, China. Lancet. 2020 Feb 15;395(10223):497-506.

16. Dienz, 0.; Rincon, M. The effects of IL-6 on CD4 T cell responses. Clin. Immunol.2009, 130, 27-33

17. Yang R, Masters AR, Fortner KA, Champagne DP, Yanguas-Casás N, Silberger DJ, et al. IL-6 promotes the differentiation of a subset of naive CD8+ T cells into IL-21-producing B helper CD8+ T cells. J Exp Med. 2016 0ct 17;213(11):2281-91.

18. Hussman JP. Cellular and Molecular Pathways of COVID-19 and Potential Points of Therapeutic Intervention. Front Pharmacol. 2020 Jul 29;11:1169.

19. Varga Z, Flammer AJ, Steiger $P$, Haberecker $M$, Andermatt $R$, Zinkernagel AS, et al. Endothelial cell infection and endotheliitis in COVID-19. Lancet. 2020 May 2;395(10234):1417-8.

20. Guan WJ, Ni ZY, Hu Y, Liang WH, Ou CQ, He JX, et al. China Medical Treatment Expert Group for Covid-19. Clinical Characteristics of Coronavirus Disease 2019 in China. N Engl J Med. 2020 Apr 30;382(18):1708-20.

21. Bhatraju PK, Ghassemieh BJ, Nichols M, Kim R, Jerome KR, Nalla AK, et al. Covid-19 in Critically III Patients in the Seattle Region - Case Series. N Engl J Med. 2020 May 21;382(21):2012-22. the pandemic amongst scientists, since, bearing in mind the great genetic variability of the coronaviruses and the frequent recombination of their genome, as well as the interaction between humans and animals, the new coronaviruses will probably develop further and cause periodical seasonal spreading of infection.

\section{Conflict of interest: None declared}

22. Richardson S, Hirsch JS, Narasimhan M, Crawford JM, McGinn T, Davidson KW, et al. Presenting Characteristics, Comorbidities, and Outcomes Among 5700 Patients Hospitalized With COVID-19 in the New York City Area. JAMA. 2020 May 26;323(20):2052-9.

23. Giacomelli A, Pezzati L, Conti F, Bernacchia D, Siano M, Oreni L, et al. Self-reported Olfactory and Taste Disorders in Patients With Severe Acute Respiratory Coronavirus 2 Infection: A Cross-sectional Study. Clin Infect Dis. 2020 Jul 28;71(15):889-90.

24. Wang Y, Liu Y, Liu L, Wang X, Luo N, Li L. Clinical Outcomes in 55 Patients With Severe Acute Respiratory Syndrome Coronavirus 2 Who Were Asymptomatic at Hospital Admission in Shenzhen, China. J Infect Dis. 2020 May 11;221(11):1770-4.

25. Mizumoto K, Kagaya K, Zarebski A, Chowell G. Estimating the asymptomatic proportion of coronavirus disease 2019 (COVID-19) cases on board the Diamond Princess cruise ship, Yokohama, Japan, 2020. Euro Surveill. 2020 Mar;25(10):2000180.

26. Pelemiš M, Stevanović $G$, Turkulov $V$, Vučinić $V$, Matijašević J, Milošević B, i saradnici. Nacionalni protokol Republike Srbije za lečenje COVID-19 infekcije, Verzija 11. 2021.

27. Wu Z, McGoogan JM. Characteristics of and Important Lessons From the Coronavirus Disease 2019 (COVID-19) Outbreak in China: Summary of a Report of 72314 Cases From the Chinese Center for Disease Control and Prevention. JAMA. 2020 Apr 7;323(13):1239-42.

28. Zhou F, Yu T, Du R, Fan G, Liu Y, Liu Z, et al. Clinical course and risk factors for mortality of adult inpatients with COVID-19 in Wuhan, China: a retrospective cohort study. Lancet. 2020 Mar 28;395(10229):1054-62.

29. Goyal P, Choi JJ, Pinheiro LC, Schenck EJ, Chen R, Jabri A, et al. Clinical Characteristics of Covid-19 in New York City. N Engl J Med. 2020 Jun 11;382(24):2372-4.

30. CDC COVID-19 Response Team. Preliminary Estimates of the Prevalence of Selected Underlying Health Conditions Among Patients with Coronavirus Disease 2019 - United States, February 12-March 28, 2020. MMWR Morb Mortal Wkly Rep. 2020 Apr 3;69(13):382-6.

31. Richardson S, Hirsch JS, Narasimhan M, Crawford JM, McGinn T, Davidson KW, et al. Presenting Characteristics, Comorbidities, and Outcomes Among 5700 Patients Hospitalized With COVID-19 in the New York City Area. JAMA. 2020 May 26;323(20):2052-9.

32. Simonnet A, Chetboun M, Poissy J, Raverdy V, Noulette J, Duhamel A, et al. High Prevalence of Obesity in Severe Acute Respiratory Syndrome Coronavirus-2 (SARS-CoV-2) Requiring Invasive Mechanical Ventilation. Obesity (Silver Spring). 2020 Jul;28(7):1195-9.

33. Milošević I, Jovanović J, Stevanovic 0. Atypical course of COVID-19 in patient with Bruton agammaglobulinemia. J Infect Dev Ctries. 2020 Nov 30;14(11):1248-51.

34. Moore JL, Ganapathiraju PV, Kurtz CP, Wainscoat B. A 63-Year-0ld Woman with a History of Non-Hodgkin Lymphoma with Persistent SARS-CoV-2 Infection Who Was Seronegative and Treated with Convalescent Plasma. Am J Case Rep. 2020 0ct 3;21:e927812. 
35. Wang D, Hu B, Hu C, Zhu F, Liu X, Zhang J, et al. Clinical Characteristics of 138 Hospitalized Patients With 2019 Novel Coronavirus-Infected Pneumonia in Wuhan, China. JAMA. 2020 Mar 17;323(11):1061-9.

36. Gupta N, Zhao YY, Evans CE. The stimulation of thrombosis by hypoxia. Thromb Res. 2019 Sep;181:77-83.

37. Tang N, Bai H, Chen X, Gong J, Li D, Sun Z. Anticoagulant treatment is associated with decreased mortality in severe coronavirus disease 2019 patients with coagulopathy. J Thromb Haemost. 2020 May;18(5):1094-9.

38. Klok FA, Kruip MJHA, van der Meer NJM, Arbous MS, Gommers DAMPJ, Kant $\mathrm{KM}$, et al. Incidence of thrombotic complications in critically ill ICU patients with COVID-19. Thromb Res. 2020 Jul;191:145-7.

39. Zhang L, Feng X, Zhang D, Jiang C, Mei H, Wang J, et al. Deep Vein Thrombosis in Hospitalized Patients With COVID-19 in Wuhan, China: Prevalence, Risk Factors, and Outcome. Circulation. 2020 Jul 14;142(2):114-28.

40. Ng JH, Bijol V, Sparks MA, Sise ME, Izzedine H, Jhaveri KD. Pathophysiology and Pathology of Acute Kidney Injury in Patients With COVID-19. Adv Chronic Kidney Dis. 2020 Sep;27(5):365-76.

41. Cevik M, Tate M, Lloyd 0, Maraolo AE, Schafers J, Ho A. SARS-CoV-2, SARSCoV, and MERS-CoV viral load dynamics, duration of viral shedding, and infectiousness: a systematic review and meta-analysis. Lancet Microbe. 2021 Jan;2(1):e13-e22.

42. Mahendiratta S, Batra G, Sarma P, Kumar H, Bansal S, Kumar S, et al. Molecular diagnosis of COVID-19 in different biologic matrix, their diagnostic validity and clinical relevance: A systematic review. Life Sci. 2020 0ct 1;258:118207.

43. Woloshin S, Patel N, Kesselheim AS. False Negative Tests for SARS-CoV-2 Infection - Challenges and Implications. N Engl J Med. 2020 Aug 6;383(6):e38.

44. Wang W, Xu Y, Gao R, Lu R, Han K, Wu G, et al. Detection of SARS-CoV-2 in Different Types of Clinical Specimens. JAMA. 2020 May 12;323(18):1843-4.

45. Krajewski R, Gołębiowska J, Makuch S, Mazur G, Agrawal S. Update on serologic testing in COVID-19. Clin Chim Acta. 2020 Nov;510:746-50.

46. Guo L, Ren L, Yang S, Xiao M, Chang D, Yang F, et al. Profiling Early Humoral Response to Diagnose Novel Coronavirus Disease (COVID-19). Clin Infect Dis. 2020 Jul 28;71(15):778-85.

47. Pilarowski G, Lebel P, Sunshine S, Liu J, Crawford E, Marquez C, et al. Performance Characteristics of a Rapid Severe Acute Respiratory Syndrome Coronavirus 2 Antigen Detection Assay at a Public Plaza Testing Site in San Francisco. J Infect Dis. 2021 Apr 8;223(7):1139-44.

48. Zhu N, Wang W, Liu Z, Liang C, Wang W, Ye F, et al. Morphogenesis and cytopathic effect of SARS-CoV-2 infection in human airway epithelial cells. Nat Commun. 2020 Aug 6;11(1):3910.

49. Wang M, Fu A, Hu B, Tong Y, Liu R, Liu Z, et al. Nanopore Targeted Sequencing for the Accurate and Comprehensive Detection of SARS-CoV-2 and Other Respiratory Viruses. Small. 2020 Aug;16(32):e2002169.

50. Huang WE, Lim B, Hsu CC, Xiong D, Wu W, Yu Y, et al. RT-LAMP for rapid diagnosis of coronavirus SARS-CoV-2. Microb Biotechnol. 2020 Jul;13(4):950-961.
51. Falzone L, Gattuso G, Tsatsakis A, Spandidos DA, Libra M. Current and innovative methods for the diagnosis of COVID19 infection (Review). Int J Mol Med. 2021 Jun;47(6):100.

52. Huang C, Wang Y, Li X, Ren L, Zhao J, Hu Y, Zhang L, et al. Clinical features of patients infected with 2019 novel coronavirus in Wuhan, China. Lancet. 2020 Feb 15;395(10223):497-506.

53. Fu L, Wang B, Yuan T, Chen $X, A 0 Y$, Fitzpatrick T, et al. Clinical characteristics of coronavirus disease 2019 (COVID-19) in China: A systematic review and meta-analysis. J Infect. 2020 Jun;80(6):656-65.

54. Zhou F, Yu T, Du R, Fan G, Liu Y, Liu Z, et al. Clinical course and risk factors for mortality of adult inpatients with COVID-19 in Wuhan, China: a retrospective cohort study. Lancet. 2020 Mar 28;395(10229):1054-1062.

55. Tang N, Li D, Wang X, Sun Z. Abnormal coagulation parameters are associated with poor prognosis in patients with novel coronavirus pneumonia. J Thromb Haemost. 2020 Apr;18(4):844-7.

56. Wang D, Hu B, Hu C, Zhu F, Liu X, Zhang J, et al. Clinical Characteristics of 138 Hospitalized Patients With 2019 Novel Coronavirus-Infected Pneumonia in Wuhan, China. JAMA. 2020 Mar 17;323(11):1061-9.

57. Kanne JP, Little BP, Chung JH, Elicker BM, Ketai LH. Essentials for Radiologists on COVID-19: An Update-Radiology Scientific Expert Panel. Radiology. 2020 Aug;296(2):E113-4.

58. Shi H, Han X, Jiang N, Cao Y, Alwalid O, Gu J, et al. Radiological findings from 81 patients with COVID-19 pneumonia in Wuhan, China: a descriptive study. Lancet Infect Dis. 2020 Apr;20(4):425-34.

59. Jacobi A, Chung M, Bernheim A, Eber C. Portable chest $X$-ray in coronavirus disease-19 (COVID-19): A pictorial review. Clin Imaging. 2020 Aug;64:35-42.

60. Izda V, Jeffries MA, Sawalha AH. COVID-19: A review of therapeutic strategies and vaccine candidates. Clin Immunol. 2021 Jan;222:108634.

61. Our World in Data. Coronavirus (COVID-19) Vaccinations [Internet]. [Cited july 2021]. Available on: https://ourworldindata.org/covid-vaccinations?country=0WID_WRL

62. Ikegame S, Siddiquey MNA, Hung CT, Haas G, Brambilla L, Oguntuyo KY, et al. Neutralizing activity of Sputnik V vaccine sera against SARS-CoV-2 variants. Nat Commun. 2021 Jul 26;12(1):4598.

63. Mahase E. Covid-19: Pfizer vaccine efficacy was $52 \%$ after first dose and $95 \%$ after second dose, paper shows. BMJ. 2020 Dec 11;371:m4826.

64. Xia S, Zhang Y, Wang Y, Wang H, Yang Y, Gao GF, et al. Safety and immunogenicity of an inactivated SARS-CoV-2 vaccine, BBIBP-CorV: a randomised, double-blind, placebo-controlled, phase 1/2 trial. Lancet Infect Dis. 2021 Jan;21(1):39-51.

65. Folegatti PM, Ewer KJ, Aley PK, Angus B, Becker S, Belij-Rammerstorfer $S$, et al. Oxford COVID Vaccine Trial Group. Safety and immunogenicity of the ChAd0x1 nCoV-19 vaccine against SARS-CoV-2: a preliminary report of a phase 1/2, single-blind, randomised controlled trial. Lancet. 2020 Aug 15;396(10249):467-78. 